\title{
Physical and economic performance of dairy cows managed within contrasting grassland-based milk production systems over 3 successive lactations
}

\author{
C. P. Ferris, ${ }^{1 *} \odot$ S. Watson, ${ }^{2}$ A. W. Gordon, ${ }^{2} \odot$ and J. Barley ${ }^{3}$ \\ ${ }^{1}$ Agri-Food and Biosciences Institute, Livestock Production Sciences Branch, Large Park, Hillsborough, County Down, Northern Ireland BT26 6DR \\ ${ }^{2}$ Agri-Food and Biosciences Institute, Statistical Services Branch, Newforge Lane, Belfast, County Antrim, Northern Ireland BT9 5PX \\ ${ }^{3}$ Agri-Food and Biosciences Institute, Disease Surveillance and Diagnostic Branch, Stoney Road, Stormont, Belfast, County Antrim, \\ Northern Ireland BT4 3SD
}

\begin{abstract}
A diverse range of grassland-based milk production systems are practiced on dairy farms in temperate regions, with systems differing in relation to the proportion of grazed grass, conserved forages and concentrates in diet, calving season, duration of housing, cow genotype, and performance levels. The current study was conducted to examine performance within diverse grassland-based systems of milk production under experimental conditions. This study examined 4 milk production systems over 3 successive lactations (20 cows per system during each lactation). With winter calving-fully housed (WC-FH), Holstein cows were housed for the entire lactation and offered a complete diet consisting of grass silage, maize silage, and concentrates [approximately $50 \%$ forage on a dry matter (DM) basis]. With winter calving-conventional (WCCon), Holstein cows were housed and offered the same diet from calving until turnout (late March) as offered with WC-FH, and thereafter cows were given access to grazing and supplemented with $5.0 \mathrm{~kg}$ of concentrate/ cow daily. Two spring-calving systems were examined, the former involving Holstein cows $(\mathrm{SC}-\mathrm{H})$ and the latter Jersey $\times$ Holstein crossbred cows $(\mathrm{SC}-\mathrm{J} \times \mathrm{H})$. Cows on these systems were offered a grass silage-concentrate mix (70\% forage on a DM basis) until turnout (late February), and thereafter cows were given access to grazing supplemented with $1.0 \mathrm{~kg}$ of concentrate/ cow per day. The contributions of concentrates $(3,080$, $2,175,722$, and $760 \mathrm{~kg}$ of $\mathrm{DM} /$ cow per lactation), conserved forages $(3,199,1,556,1,053$, and $1,066 \mathrm{~kg}$ of DM/cow per lactation), and grazed grass ( $0,2,041$, 2,788 , and $2,692 \mathrm{~kg}$ of $\mathrm{DM} /$ cow per lactation) to total DMI $(6,362,5,763,4,563$, and $4,473 \mathrm{~kg}$ of DM/cow per
\end{abstract}

Received February 16, 2021.

Accepted December 11, 2021.

*Corresponding author: conrad.ferris@afbini.gov.uk lactation) with WC-FH, WC-Con, SC-H, and SC-J $\times \mathrm{H}$, respectively, varied considerably. Similarly, milk yield $(9,333,8,443,6,464$, and $6,049 \mathrm{~kg} / \mathrm{cow}$ per lactation $)$, milk fat content $(44.9,43.3,42.8$, and $49.0 \mathrm{~g} / \mathrm{kg})$, and milk protein content $(34.6,34.9,33.6$, and $36.3 \mathrm{~g} / \mathrm{kg}$ ) differed between systems (WC-FH, WC-Con, SC-H, and $\mathrm{SC}-\mathrm{J} \times \mathrm{H}$, respectively). The higher milk yields with the WC systems reflect the greater concentrate inputs with these systems, whereas the greater milk fat and protein content with $\mathrm{SC}-\mathrm{J} \times \mathrm{H}$ reflect the use of Jersey crossbred cows. Crossbred cows on $\mathrm{SC}-\mathrm{J} \times \mathrm{H}$ produced a similar yield of milk solids as Holstein cows on SC-H. Cows on WC-FH ended the lactation with a greater body weight (BW) and body condition score than cows on any other treatment. While Jersey crossbred cows on $\mathrm{SC}-\mathrm{J} \times \mathrm{H}$ had a lower BW than Holstein cows on $\mathrm{SC}-\mathrm{H}$, cows on these 2 systems were not different for any of the other BW, body condition score, or blood metabolite parameters examined. Cows on WC-FH had a greater interval from calving to conception, a greater mastitis incidence, and a greater locomotion score than cows on the spring calving systems. Whole-system stocking rates and annual milk outputs were calculated as 2.99, 2.62, 2.48, and 2.50 cows/ha, and 25,706, $20,822,15,289$, and $14,564 \mathrm{~kg}$ of milk/ha, with each of WC-FH, WC-Con, SC-H, and SC-J $\times \mathrm{H}$, respectively. Gross margin per cow was highest with WC-Con, gross margin per hectare was highest with $\mathrm{WC}-\mathrm{FH}$, and gross margin per kilogram of milk was highest with $\mathrm{SC}-\mathrm{J} \times \mathrm{H}$. This study demonstrated that diverse grassland-based milk production systems are associated with very different levels of performance when examined per cow and per hectare.

Key words: dairy cattle, fully housed, Jersey crossbreds, grassland systems

\section{INTRODUCTION}

Although grassland-based milk production systems are common in many parts of the world, including with- 
in cool temperate regions of western Europe, there is much variation in systems adopted between and within grassland regions. For example, grassland systems adopted within the United Kingdom and Ireland differ in calving season, the relative proportions of grazed grass, grass silage (and other forages), and concentrates in cow diets, and the degree of housing. In addition, although the Holstein-Friesian is the predominant dairy cow genotype within the United Kingdom and Ireland, many farmers, especially those operating lower input systems, make use of alternative cow genotypes. As a consequence, annual milk production of cows within grassland systems can vary considerably.

Giving cows access to grazing can have many advantages, including improved cow health and welfare (Arnott et al., 2017) and the production of milk with a lower environmental footprint (O'Brien et al., 2012) and enhanced health characteristics (Vance et al., 2012b). In addition, production costs decrease as the proportion of grazed grass in dairy cow diets increase (Dillon et al., 2008), whereas there is evidence of consumer preference for livestock products from pasture-based systems (Stampa et al., 2020). However, despite these advantages, the importance of grazed grass within dairy cow diets has declined within many grassland regions, with this reflected in an increased reliance on concentrate feedstuffs, and the adoption of systems involving either complete or partial housing during the grazing season. For example, a survey in Great Britain indicated that $46 \%$ of herds spend either part or all of their time housed during the summer (March et al., 2014).

There are many reasons for this intensification of grassland systems, including the increasing milk yield potential of dairy cows in many countries and the associated challenges in meeting the higher nutrient requirements of these higher-yielding cows (Ferris et al., 2003). In addition, it is generally easier to achieve the higher concentrate intakes necessary to meet the greater nutrient requirements of higher-yielding cows when they are housed rather than grazing, as grazing cows generally only consume concentrates when being milked. Increasing dairy herd size in many grassland regions has also contributed to the increased adoption of confinement during the grazing season, with this often due to the grazing platform (i.e., the fields that the cows can easily access from the milking parlor) no longer being sufficient for larger herds. Furthermore, automatic milking systems have become increasingly common in many countries (Barkema et al., 2015), and these are generally more suited to confinement-based systems.

While the relative merits of the wide range of grassland systems adopted within the United Kingdom and
Ireland (and indeed in other parts of the world) are often debated, robust scientific data comparing physical performance across complete lactations within these diverse systems is scarce. This is largely due to the prohibitive cost of systems-type research, which ideally needs to be conducted over several years to take account of year-to-year variation in seasonal weather patterns, and their associated effects on herbage production and utilization. Nevertheless, several comparisons have been made. For example, Gordon et al. (2000) and Ferris et al. (2003), in studies encompassing one full lactation, compared winter calving systems differing in concentrate inputs, with the latter study demonstrating that similar levels of cow performance could be achieved under very different concentrate input-grazing management-silage quality scenarios. Similarly, the effects of different concentrate inputs and cow genotypes have been examined within spring-calving milk production systems (Vance et al., 2013; Ferris et al., 2018). However, only the former study was conducted over multiple lactations. In addition, although many recent studies have compared the effect of grazing versus housing, most of these studies were short term and involved only part of a lactation. In 2 exceptions, Vance et al. (2013) and O'Callaghan et al. (2016) compared the performance of spring-calving cows over a full lactation within either a fully housed system or a lower input grazing system. However, no studies comparing winter- and spring-calving milk production systems, or fully housed and conventional winter calving systems, have been identified.

Therefore, the current study was conducted to compare the physical and economic performance associated with 4 diverse milk production systems, all of which are currently adopted within the United Kingdom and Ireland. The inclusion of a higher input-higher output fully housed system reflects the increasing adoption of such systems within the United Kingdom (March et al., 2014), with these systems having potential to maximize milk output per hectare. At the other extreme, the lower input-lower output spring-calving systems were included within the study (with both Holstein and with crossbred cows) as these systems are often considered to be low cost and to represent a more sustainable approach to milk production, although with a lower milk output per hectare. These spring-calving systems, while reasonably common within the United Kingdom, predominate in the Republic of Ireland. The fourth system (winter calving with grazing during the summer) was chosen to represent what remains the most common system within the United Kingdom, namely a moderate input-moderate output system. The study was conducted over 3 successive lactations to overcome 
some of the year-to-year variation associated with grassland-based systems. The environmental impact of these systems will be examined separately.

\section{MATERIALS AND METHODS}

This experiment was conducted at the Agri-Food and Biosciences Institute (AFBI; 54 $27^{\prime} \mathrm{N} ; 06^{\circ} 04^{\prime} \mathrm{W}$ ), Hillsborough, Northern Ireland (NI), between October 2008 and December 2011. All experimental procedures in this study were conducted under an experimental license granted by the Department of Health, Social Services and Public Safety for NI in accordance with the Animals (Scientific Procedures) Act 1986.

\section{Cows and Allocation to Systems}

Eighty dairy cows were managed on 1 of 4 grassland-based milk production systems over 3 successive lactations. Key aspects of each of the 4 management systems are summarized in Table 1, whereas key dates associated with each system are presented in Table 2 .

Three of these systems involved Holstein cows $(\mathrm{n}=$ 20 per system/year) and one system involved Jersey $x$ Holstein crossbred $\left(\mathrm{F}_{1}\right)$ cows (20 per year). Two of the 4 systems involved winter-calving (WC) cows and 2 involved spring-calving (SC) cows. The systems were as follows: (1) winter calving-fully housed (WC-FH), (2) winter calving-conventional (WC-Con), (3) spring calving with Holstein cows (SC-H), and (4) spring calving with Jersey $\times$ Holstein crossbred cows $($ SC$\mathbf{J} \times \mathbf{H})$.

Cows on WC-FH and WC-Con calved between October and April each year (mean calving dates, Table 2 ). Cows allocated to these 2 systems were balanced for calving date, parity, sire, and PTA for fat plus protein yield. Cows on SC-H and SC-J $\times$ H calved between January and April each year (mean calving dates, Table 2). Cows allocated to $\mathrm{SC}-\mathrm{H}$ and $\mathrm{SC}-\mathrm{J} \times \mathrm{H}$ were balanced for calving date, parity, and dam PTA for fat + protein yield. The Jersey $\times$ Holstein crossbred cows on SC$\mathrm{J} \times \mathrm{H}$ were the offspring of a breeding program involving randomly selected Holstein-Friesian cows from the AFBI-Hillsborough herd, and were bred to Jersey sires of both Danish and New Zealand origin, as described by Vance et al. (2012b).

The study commenced with 15 multiparous cows and 5 primiparous cows on each system. Cows remained on the same management system for the duration of the experiment, or until removed from the experiment. Cows that were removed during, or at the end of yr 1 and 2, were replaced at the start of yr 2 and 3, respectively. Replacement animals were primiparous and

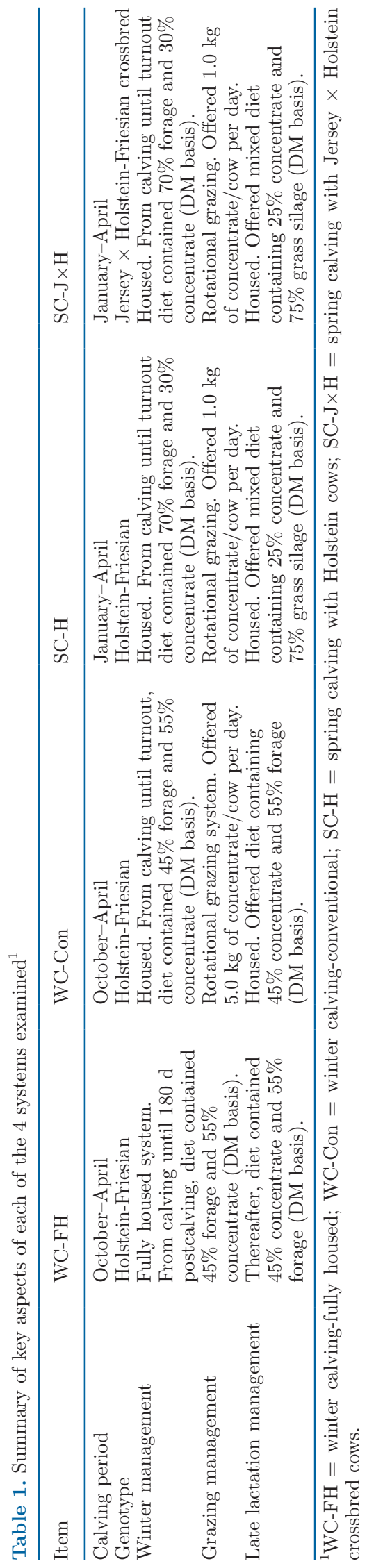


were balanced across systems according to the traits described above.

\section{Housing}

Cows were transferred to cubicle accommodation within $36 \mathrm{~h}$ of calving. Cubicles were fitted with rubber mats which were scraped down daily, bedded with sawdust 3 times weekly, and treated with lime weekly. Sufficient cubicles (approximately 10\% excess) were available for all cows within each group. The concrete walkways within the house were scrapped a minimum of 6 times each day by an automatic scrapper system. When housed, cows accessed their diets via a Calan gate feeding system (American Calan). Each Calan gate was linked to an automatic cow identification system, which allowed cows to gain access to a feed box mounted on a weigh scale (Griffith Elder), thus allowing individual cow food intakes to be measured.

\section{Description of Management Systems}

The ingredient composition of each of the concentrates offered during the experiment, and their mean chemical composition (during the $3 \mathrm{yr}$ of the experiment), are presented in Table 2. Changes in the availability and cost of some ingredients meant that the ingredient composition of the concentrates offered throughout the experiment varied from year to year. The mean chemical composition of the grass silage, maize silage, and grazed grass offered during the $3 \mathrm{yr}$ of the experiment is presented in Table 4 .

\section{Systems WC-FH and WC-Con}

Cows on WC-FH were housed throughout the experiment. Once transferred to the experimental group following calving, cows were offered a mixed ration containing concentrates (pre d-180 concentrate) and forage (55:45 DM ratio), with the forage component of the ration consisting of grass silage and maize silage $(80: 20$ DM ratio). In addition, all cows were offered $1.0 \mathrm{~kg}$ of concentrate $/ \mathrm{d}$ (0.5 kg at each milking) using in-parlor feeders. When cows on this treatment were a mean of $180 \mathrm{~d}$ calved, the concentrate offered was changed to the post d-180 concentrate, and the concentrate:forage DM ratio in the mixed ration was reduced to 45:55 (the grass silage:maize silage DM ratio within the forage mix remained unchanged at 80:20). Cows remained on this diet until drying off (mean drying-off dates in Table 2).

Cows on WC-Con were managed identically to those on WC-FH until the commencement of the grazing period (start of grazing dates in Table 2). Cows grazed initially for approximately $8 \mathrm{~h} / \mathrm{d}$ (milking-to-milking), with full-time turnout achieved on April 16, April 19, and April 14 (yr 1-3, respectively). During this tran-

Table 2. Summary of key dates associated with each system over the $3 \mathrm{yr}$ of the study ${ }^{1,2}$

\begin{tabular}{|c|c|c|c|c|}
\hline Item & WC-FH & WC-Con & $\mathrm{SC}-\mathrm{H}$ & $\mathrm{SC}-\mathrm{J} \times \mathrm{H}$ \\
\hline \multicolumn{5}{|l|}{ Year 1} \\
\hline Calving date & $11 / 18 / 2008$ & $11 / 21 / 2008$ & 02/04/2009 & $02 / 08 / 2009$ \\
\hline Start part-time grazing & $\mathrm{NA}^{3}$ & $03 / 29 / 2009$ & $03 / 09 / 2009$ & $03 / 09 / 2009$ \\
\hline Start full-time grazing & NA & $04 / 16 / 2009$ & $04 / 02 / 2009$ & $04 / 02 / 2009$ \\
\hline Start part-time rehousing & NA & NÁ & $10 / 19 / 2009$ & $10 / 19 / 2009$ \\
\hline Start full-time rehousing & NA & $10 / 19 / 2009$ & $10 / 23 / 2009$ & $10 / 23 / 2009$ \\
\hline Dry-off date & $10 / 08 / 2009$ & $10 / 08 / 2009$ & $11 / 11 / 2009$ & $12 / 01 / 2009$ \\
\hline \multicolumn{5}{|l|}{ Year 2} \\
\hline Calving date & $12 / 14 / 2009$ & $12 / 12 / 2009$ & $02 / 01 / 2010$ & $02 / 07 / 2010$ \\
\hline Start part-time grazing & NA & $03 / 27 / 2010$ & $02 / 09 / 2010$ & $02 / 09 / 2010$ \\
\hline Start full-time grazing & NA & $04 / 19 / 2010$ & $04 / 21 / 2010$ & $04 / 21 / 2010$ \\
\hline Start part-time rehousing & NA & $10 / 02 / 2010$ & $10 / 22 / 2010$ & $10 / 22 / 2010$ \\
\hline Start full-time rehousing & NA & $11 / 01 / 2010$ & $11 / 01 / 2010$ & $11 / 01 / 2010$ \\
\hline Dry-off date & $11 / 06 / 2010$ & $10 / 07 / 2010$ & $12 / 10 / 2010$ & $12 / 12 / 2010$ \\
\hline \multicolumn{5}{|l|}{ Year 3} \\
\hline Calving date & $12 / 24 / 2010$ & $12 / 07 / 2010$ & $02 / 20 / 2011$ & $02 / 11 / 2011$ \\
\hline Start part-time grazing & NA & $03 / 29 / 2011$ & $02 / 26 / 2011$ & $02 / 26 / 2011$ \\
\hline Start full-time grazing & NA & $04 / 14 / 2011$ & $04 / 14 / 2011$ & $04 / 14 / 2011$ \\
\hline Start part-time rehousing & NA & $10 / 09 / 2011$ & $10 / 09 / 2011$ & $10 / 09 / 2011$ \\
\hline Start full-time rehousing & NA & $10 / 25 / 2011$ & $11 / 09 / 2011$ & $11 / 09 / 2011$ \\
\hline Dry-off date & $10 / 14 / 2011$ & $10 / 15 / 2011$ & $12 / 09 / 2011$ & $12 / 04 / 2011$ \\
\hline
\end{tabular}

${ }^{1} \mathrm{WC}-\mathrm{FH}=$ winter calving-fully housed; $\mathrm{WC}-\mathrm{Con}=$ winter calving-conventional; $\mathrm{SC}-\mathrm{H}=$ spring calving with Holstein cows; SC-J $\times \mathrm{H}=$ spring calving with Jersey $\times$ Holstein crossbred cows.

${ }^{2}$ Dates are shown as month/day/year.

${ }^{3}$ Not applicable. 
sition period the proportion of concentrates included within the mixed ration was gradually reduced, whereas $4.0 \mathrm{~kg} /$ cow per day of a grazing concentrate (Table 3) was offered using an in-parlor concentrate feeder, $2.0 \mathrm{~kg}$ at each milking. At full-time turnout the concentrate offered via the in-parlor feeder was increased to the target level of $5.0 \mathrm{~kg} / \mathrm{cow}$ per day. On several occasions during the 3-yr experiment, herbage shortages required that concentrate feed levels were increased (to either 6.0 or $7.0 \mathrm{~kg} /$ cow per day), with these short-term adjustments in feed levels lasting for between 1 and 3 wk. Cows grazed full time until October, with full-time housing dates in Table 2. During this transition from full-time grazing to full-time rehousing, cows normally grazed during the day (between morning and evening milking) and were housed at night and offered the grass silage and maize silage in the same ratio as cows on WC-FH, while continuing to be offered their full grazing concentrate allowance via the in-parlor feeder. Following full-time rehousing, cows moved onto the post d-180 ration, as described for WC-FH. Cows remained on this diet until drying-off (mean drying-off dates in Table 2).

\section{Systems SC-H and SC-J $\times H$}

From calving until the start of turnout, the mixed ration offered consisted of grass silage and concentrates (70:30 DM ratio), together with $1.0 \mathrm{~kg}$ of concentrate/ cow per day offered via an in-parlor feeder $(0.5 \mathrm{~kg}$ at each milking). The ingredient composition of this concentrate is presented in Table 3 . Cows on these 2 systems commenced grazing on March 9, February 9, and February 26 during yr 1 to 3, respectively, with dates for start of full-time grazing in Table 2. During this transition period the duration of the daily grazing period increased from approximately $2 \mathrm{~h} / \mathrm{d}$ to approximately 12 h/d (0800-2000 h), before full-time grazing commencing, while cows were allocated sufficient herbage to allow them to graze to a residual sward height of approximately $5.0 \mathrm{~cm}$ (measured using a plate meter, as described later). During the nongrazing part of the day cows were initially offered the postcalving ration described previously. However, partway through this transition period (March 21, April 12, and March 30, in yr 1-3, respectively), the concentrate component of the mixed ration was reduced, and $4.0 \mathrm{~kg} / \mathrm{d}$ of a grazing concentrate (Table 3) was introduced into the diet (offered via an in-parlor feeder: $2.0 \mathrm{~kg}$ at each milking). Following full-time turnout, concentrates offered via the in-parlor feeder were reduced over a $10-$ to $20-\mathrm{d}$ period until the target concentrate feed level of $1.0 \mathrm{~kg}$ of concentrate/cow per day was achieved. On several occasions during the grazing season, as a result of adverse weather or grass shortages (especially in late lactation), concentrate levels were increased to $2.0 \mathrm{~kg} / \mathrm{cow}$ per day. During the early part of the grazing period (from fulltime turnout until the risk period was deemed to have passed, normally late April or early May) paddocks were dusted with calcined magnesite $(210 \mathrm{~g} / \mathrm{cow}$ per day) on a daily basis to ensure cows had an adequate intake of magnesium.

Cows continued to graze full time until October, followed by a period of part-time grazing (grazing by day, and being offered grass silage by night), with dates of full-time rehousing in Table 2. Following full-time rehousing cows were offered a mixed ration consisting of grass silage and concentrate (75:25 DM ratio), plus 1.0 $\mathrm{kg}$ of concentrate/cow per day via an in-parlor feeder, until drying off.

\section{Dry Period}

Cows that were nonpregnant remained on their experimental diet for the same mean number of days as the pregnant cows within their system that year, after which they were removed from the experiment. Pregnant cows with a BCS of $\geq 2.50,2.25$, and $\leq 2.00$ were dried off 8,10 , and 12 wk precalving, respectively, and cows were also dried off if average weekly milk yields fell below $5.0 \mathrm{~kg} / \mathrm{d}$. Cows were dried off abruptly following morning milking and treated with long-acting antibiotic tubes and a teat sealant. Cows on WC-FH cows were housed throughout the dry period. With $\mathrm{WC}$, cows that were dried off early in the autumn were grazed without supplementation within the defined grazing area for that system (mean of 17 grazing d/cow per year) until $3 \mathrm{wk}$ precalving, before being housed. Cows dried off after mid-October were housed immediately. Cows on the SC systems were rehoused at dryoff. While housed, dry cows on all systems were offered a grass silage, which was supplemented with $100 \mathrm{~g} / \mathrm{cow}$ per day of a dry-cow mineral and vitamin supplement. While housed, dry cows were kept in a dry-cow group and their intakes measured using the Calan gate system described earlier.

\section{Culling}

Cows that were removed from the experiment due to health problems during the grazing season were replaced with nonexperimental cows until the end of that grazing season to maintain grazing group sizes (20 cows per system). Cows removed either during or at the end of yr 1 and 2 were replaced by new experimental cows at the start of the subsequent lactation, as described previously. 
Ferris et al.: GRASSLAND-BASED MILK PRODUCTION SYSTEMS

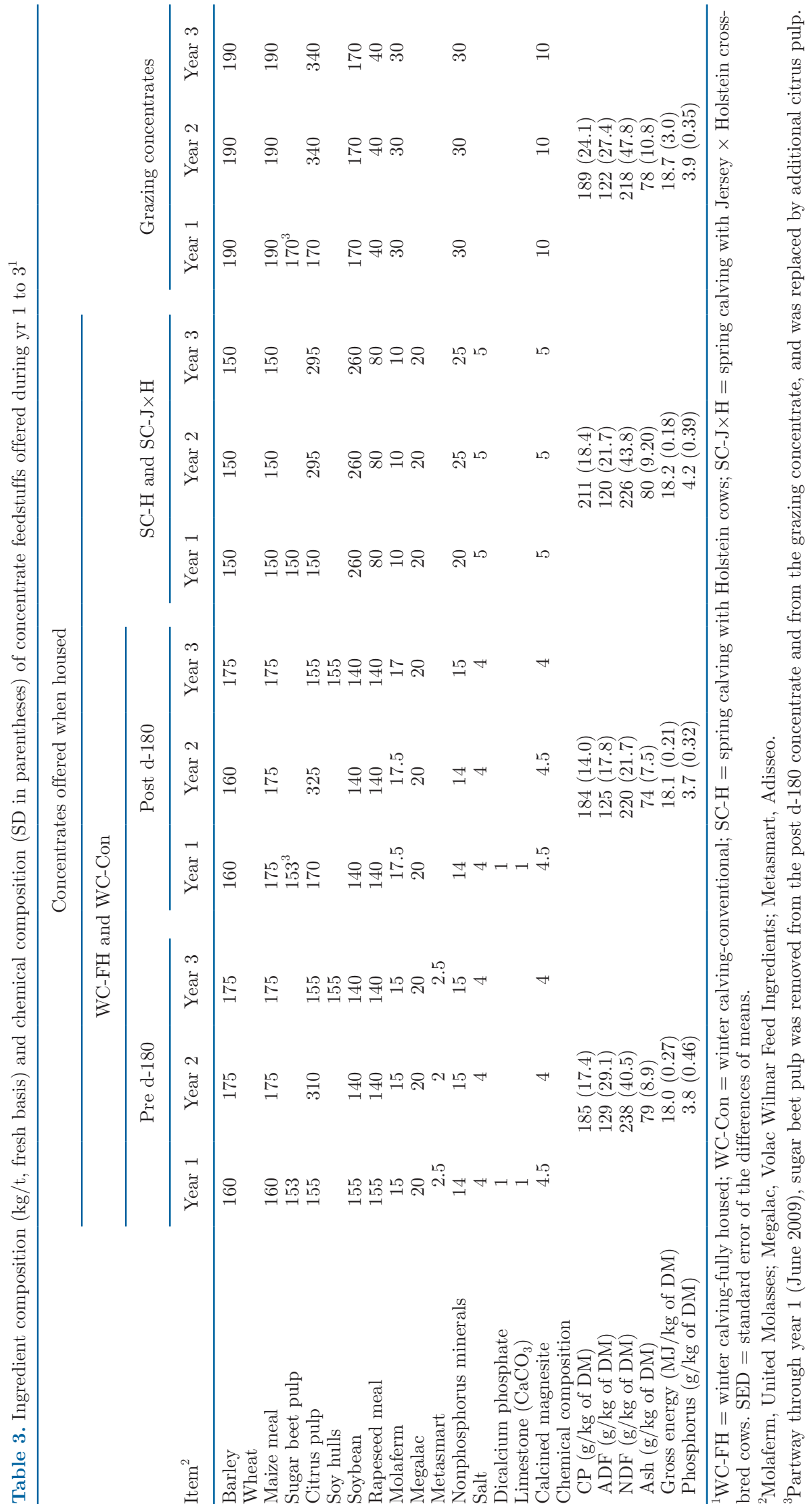




\section{Breeding Program}

Throughout the experiment cows were bred via AI, approximately $12 \mathrm{~h}$ after visual observation of estrus. For cows on WC systems, breeding commenced during the first week of December, and continued mid-July. With the SC systems a 14-wk breeding season was adopted, commencing the first week of April and finishing mid-July. A minimum voluntary waiting period of $42 \mathrm{~d}$ was adopted before the start of breeding. Holstein cows were bred to Holstein sires (a pool of common sires was used across all 3 systems each year), whereas crossbred cows were bred to sires of the Swedish Red and White breed, as part of a 3-breed crossing program. Pregnancy was diagnosed via rectal scanning approximately $60 \mathrm{~d}$ post AI. Cows were not treated with any fertility drugs until they were a minimum of $52 \mathrm{~d}$ calved. The exception to this were cows that displayed symptoms of uterine infection, in which case treatment was given as soon as the problem was identified. Cows with no observed estrus before d 52 postcalving were inspected by a veterinary surgeon, and treated as appropriate.

\section{Diet Preparation While Housed}

With the WC systems, sufficient silage (grass silage and maize silage) for these 2 systems was placed in a diet mixer wagon (Redrock) and mixed for approximately $5 \mathrm{~min}$. The required quantity of concentrates was then added to the silage in the mixer wagon, and mixing continued for a further $5 \mathrm{~min}$. This mixed ration was then offered via the Calan gate feeding system described previously. With the SC systems, sufficient grass silage and concentrates for these 2 systems was placed in the mixer wagon, and mixed for approximately $5 \mathrm{~min}$, before being offered via the Calan gate system, as described earlier. All mixed rations were offered at proportionately 1.07 of the previous day's intake. Uneaten food was removed from the feed boxes daily at approximately 0830 to $0900 \mathrm{~h}$, and fresh food offered at between 0900 and $1030 \mathrm{~h}$.

\section{Silages Offered}

Grass silages offered were harvested from predominantly perennial ryegrass (Lolium perenne)-based swards using a self-propelled precision chop forage harvester, treated with a bacterial inoculant at harvest, and ensiled in walled silos. With WC-FH, the grass silages offered were produced from primary growth, primary regrowth, and secondary regrowth herbage, with these silages offered for approximately proportionally 0.40 , 0.35 , and 0.25 of the total cow feeding days within the experiment, respectively. These proportions represented herbage yields for primary growth, primary regrowth, and secondary regrowth harvests within a 3-harvest grass silage system (Mayne and Gordon, 1986). Silages offered before turnout with the WC and SC systems were produced predominantly from primary growth herbage, whereas silages offered following rehousing were predominantly produced from secondary regrowth herbages. Silages offered to dry cows on all systems were predominantly produced from secondary regrowth herbage. Maize silage offered was sown under plastic in spring each year, and harvested between mid-October and early November.

\section{Grazing Management}

The grazing area (approximately 22 ha in total) consisted of a perennial ryegrass-based sward. Cows on systems $\mathrm{WC}-\mathrm{Con}, \mathrm{SC}-\mathrm{H}$, and $\mathrm{SC}-\mathrm{J} \times \mathrm{H}$ were managed within a rotational paddock grazing system, with twenty-one 1-d paddocks (paddock size of 0.17, 0.20, and 0.20 ha for $\mathrm{WC}-\mathrm{Con}$, SC-H, and $\mathrm{SC}-\mathrm{J} \times \mathrm{H}$, respectively) initially established for each system. Paddocks for each of the 3 systems were established across the grazing area, taking account of variations in sward and soil quality, and land topography. Target pre- and postgrazing herbage masses (above ground level) were 3,000 and $1,800 \mathrm{~kg}$ of $\mathrm{DM} / \mathrm{ha}$, respectively, with each of WC-Con, SC-H, and SC-J $\times$ H. Herbage mass was estimated from grass heights (the latter determined using a plate meter, as described below) using the equation presented by Vance et al. (2012b). Additional grazing paddocks were introduced into the rotation as the season progressed, and paddocks that were not grazed during a rotation (due to excess grass being available, as determined by a grass wedge grassland management tool) were either grazed by a group of nonexperimental cows, or cut and baled for silage. Cows on all systems completed 8 grazing cycles in yr 1, 9 grazing cycles in yr 2, and 10 grazing cycles in yr 3 . Across the $3 \mathrm{yr}$ of the experiment the mean numbers of grazing days within the first 8 grazing cycles were 25.3, 19.0, 20.7, $21.3,23.3,21.3,23.0$, and 21.3 for WC-Con, and 32.3, $22.0,20.3,22.7,23.3,21.3,24.3$, and $24.3 \mathrm{~d}$ for SC-H and $\mathrm{SC}-\mathrm{J} \times \mathrm{H}$. Over the entire grazing season, the mean stocking rates on the grazing platform with WC-Con, $\mathrm{SC}-\mathrm{H}$, and $\mathrm{SC}-\mathrm{J} \times \mathrm{H}$ were $5.1,4.4$, and $4.4 \mathrm{cows} / \mathrm{ha}$ in yr $1,5.0,4.3$, and 4.3 cows per ha in yr 2 , and $5.2,4.3$, and 4.3 cows per ha in year 3 , respectively.

Target inorganic fertilizer $\mathrm{N}$ application levels were as follows: a pre-grazing application of urea (proportionally $0.46 \mathrm{~N}$ ) across the grazing area before turnout at $28 \mathrm{~kg} \mathrm{~N} /$ ha, followed thereafter by calcium ammonium nitrate (proportionally $0.27 \mathrm{~N}$ ) at a rate of 45,30 , $30,30,25,25$ following each of grazing cycles 1 to 7 , 
respectively, and $20 \mathrm{~kg} \mathrm{~N} /$ ha following any subsequent grazing cycles. Actual applications with WC-Con, SC$\mathrm{H}$, and $\mathrm{SC}-\mathrm{J} \times \mathrm{H}$ were 233,230 , and $230 \mathrm{~kg} \mathrm{~N} / \mathrm{ha}$ in $\mathrm{yr}$ $1,240,244$, and $244 \mathrm{~kg} \mathrm{~N} /$ ha in yr 2, and 235, 233, and $233 \mathrm{~kg} \mathrm{~N} /$ ha in yr 3, respectively. The entire grazing area was trimmed ("topped") to approximately $50 \mathrm{~mm}$ midway through each grazing season. Throughout the grazing season pre- and postgrazing sward heights (40 measurements in a $\mathrm{W}$ formation) were recorded daily using a rising plate meter (Jenquip) within the grazing paddocks for each of WC-Con, SC-H, and SC-J $\times$ H. Mean pre- and postgrazing sward heights for WC-Con were $8.7,8.7$, and $8.8 \mathrm{~cm}$, and $5.0,5.3$, and $5.0 \mathrm{~cm}$ for yr 1 to 3 , respectively. Respective values for SC-H were $8.6,8.9$, and $9.1 \mathrm{~cm}$, and $4.8,5.3$, and $5.0 \mathrm{~cm}$, whereas those for SC-J $\times \mathrm{H}$ were $8.7,8.5$, and $8.7 \mathrm{~cm}$ and 4.8 , 5.2 , and $4.7 \mathrm{~cm}$.

\section{Measurements}

Animal Measurements. Cows were milked twice daily between 0600 and $0800 \mathrm{~h}$ and between 1500 and $1700 \mathrm{~h}$, with milk yields recorded automatically at each milking. Milk fat, protein, and lactose concentrations were determined weekly using 2 consecutive (morning and evening) milk samples (Milkoscan, model FT 120, Foss Electric) whereas milk SCC was determined monthly using a Fossomatic 360 (Foss Electric). Milk samples were preserved (Lactab Mark III, Thompson and Cooper Ltd.) and stored at $4^{\circ} \mathrm{C}$ until analyzed. Cow BW was recorded automatically after each milking and an average weekly BW subsequently calculated. The BCS of lactating cows was assessed fortnightly by a trained operator using a 5-point scale (including quarter points; Edmondson et al., 1989), where $1=$ emaciated and $5=$ extremely fat. Locomotion score was recorded fortnightly by a single trained operator using a 5-point scale (Manson and Leaver, 1988), where $1=$ no unevenness in gait or tenderness and $5=$ difficulty in walking and adverse effects on behavior pattern. Blood samples were taken from the tail of each cow after morning milking, at wk 2, 6, 10 ( \pm 3 d), 20, 30, and $40( \pm 7 \mathrm{~d})$ postcalving. Blood plasma was recovered via centrifugation and stored at $-20^{\circ} \mathrm{C}$ until analysis for BHB, nonesterified fatty acids (NEFA), glucose, and urea as described by Little et al. (2016).

During the periods when cows on each of the 4 systems were housed, individual cow intakes were measured daily using the Calan gates feeding system described previously. During the grazing season (from start of turnout to full-time rehousing) mean daily herbage DMI of lactating cows were calculated weekly for each cow from cow performance data, and total herbage intake over the grazing season subsequently calculated.
Within this calculation, milk energy content was determined from weekly milk samples using the equations of Tyrrell and Reid (1965), whereas mean daily BW change over the grazing period (full-time grazing period only) was determined by linear regression of weekly BW data. Total energy required for maintenance, production, tissue change, pregnancy (where appropriate), and walking (assumed as $2.0 \mathrm{~km} / \mathrm{d}$ for cows grazing full time) was determined using the equations contained within Feed into Milk (FIM), the UK dairy cow feed rationing system (Agnew et al., 2004). The ME content of herbage was measured using near-infrared reflectance spectroscopy (NIRS), as described below, whereas the ME content of the grazing concentrates offered was assumed as $12.4 \mathrm{MJ} / \mathrm{kg}$ of DM (based on published values for individual ingredients: FeedByte, SRUC).

During the part-turnout and part-rehousing periods (at the start and end of the grazing season respectively), the calculation of herbage intakes took account of ME intake from grass silage, maize silage, and the concentrates consumed when housed. However, no account was taken of BW change at this time due to large rumen fill-associated changes in BW during these transition times. Herbage intakes of nonlactating grazing cows were determined using a similar technique, with the calculation taking account of the energy required for maintenance and pregnancy only, but not BW change. The latter were excluded as it was not possible to differentiate true BW change associated with either tissue mobilization or deposition, and BW change associated with the growing fetus.

Cows with health problems were treated by either a veterinary surgeon or by a member of AFBI staff, as appropriate. All incidences of mastitis and lameness were recorded throughout the experiment, with an incidence defined as one where the cow was treated with an antibiotic.

Feed Chemical Analysis. Grass and maize silages offered were sampled daily and analyzed for oven DM content, and dried samples were retained weekly, bulked for each 4-wk period, and subsequently analyzed for $\mathrm{ADF}, \mathrm{NDF}$, and ash concentrations. In addition, maize silage samples were dried at $60^{\circ} \mathrm{C}$ on one occasion each week, bulked for each 4-wk period, and analyzed for starch content. Fresh silages were analyzed weekly for gross energy $(\mathbf{G E}), \mathrm{N}, \mathrm{pH}$, ammonia $\mathrm{N}$, and volatile components, whereas the ME content of fresh silage was estimated weekly using NIRS, as described by Park et al. (1998). During the grazing season herbage pluck samples were taken within the grazing area for each system once weekly, and dried at $60^{\circ} \mathrm{C}$. Dried samples were bulked for each 2-week period and analyzed for ADF, NDF, N, GE, water-soluble carbohydrate, and ash concentrations. In addition, a fresh sample of grass 
from the grazing area within each system was analyzed weekly for ME content using NIRS as described by Park et al. (1998) for grass silage, but using a calibration equation developed for fresh grass. A sample of each concentrate type offered was collected weekly, with samples bulked for each 4 -wk period and analyzed for N, ADF, NDF, GE, ash, and P content. The feedstuffs offered were analyzed as described by Purcell et al. (2016).

\section{Economic Performance}

The economic performance of each system was modeled, as follows. Mean lactation milk production data from each system over the $3 \mathrm{yr}$ of the study were adjusted to an annual basis. This adjustment involved multiplying the full lactation milk production data by 0.92, 0.94, 0.95, and 0.96 (systems WC-FH, WC-Con, $\mathrm{SC}-\mathrm{H}$, and $\mathrm{SC}-\mathrm{J} \times \mathrm{H}$, respectively), to obtain annual data. These adjustment factors were determined for each system as $365 /$ (average lactation days + average dry days). The economic analysis was initially undertaken at a milk base price of $£ 0.28 \mathrm{~kg}$ of milk ( $\$ 1 \mathrm{USD}$ $=£ 0.64$ GBP; Dec. 31, 2011), with milk price adjusted for compositional bonuses, as follows: a bonus or deduction of 0.022 pence for every $0.1 \mathrm{~g} / \mathrm{kg}$ above or below a base level of $38.5 \mathrm{~g} / \mathrm{kg}$ fat, and a bonus or deduction of 0.036 pence for every $0.1 \mathrm{~g} / \mathrm{kg}$ above or below a base level of $31.8 \mathrm{~g} / \mathrm{kg}$ protein (based on current payment structure in NI). Replacement rates and stillbirth rates (used in calculation of young stock and cull cows sold of the farm) were obtained from a study comparing Holstein and Jersey $\times$ Holstein crossbred cows on 11 NI farms (Ferris, 2012). Stillbirths were assumed as 12\% and $8 \%$ for Holstein and Jersey crossbred heifers at first calving, and $3 \%$ and $2 \%$ for Holstein and Jersey crossbred cows at subsequent calvings, respectively. A replacement rate of $27.6 \%$ was adopted for each of the 3 systems involving Holstein cows, and a value of $20.5 \%$ for SC-J $\times$ H. A $14.5 \%$ loss of young stock between birth and calving at $2 \mathrm{yr}$ of age was assumed for both genotypes (Wathes et al., 2008). All male calves, and female calves that were surplus to breeding requirements, were assumed sold at birth. The value of the Holstein calves sold was assumed as $£ 100$ (bull) and $£ 180$ (heifer), whereas the value of Jersey crossbred calves sold was assumed as $£ 50$ (bull) and $£ 180$ (heifer). Holstein cull cows were assumed sold at the end of their lactation and to have a value of $£ 650$ (DAERA, 2020), whereas crossbred cull cows were assumed to have a value of $£ 507$ (22\% lower, based on the actual differential in value of cull cows of both genotypes sold from the AFBI herd between 2012 and 2013). The cost of replacement heifers was assumed to be the same for both breeds
( 11,300 : DAERA, 2020). Total outputs ( $£ /$ cow per yr) were determined as the value of milk, calves, and cull cows sold, less the annual replacement charge.

Variable costs included in the analysis consisted of feed costs plus sundries. Mean lactation intakes of each dietary component from each system (over the $3 \mathrm{yr}$ of the study) were adjusted to an annual basis, as described earlier for lactation milk outputs. Cash costs adopted for grass silage (3 harvest system), maize silage, and grazed grass were $£ 91, £ 75, £ 31 /$ t of DM, respectively (Craig et al., 2021), whereas the cost of all concentrates was assumed as $£ 250 /$ t fresh. Sundry costs (veterinary, medicine, AI, and so on) were derived from DAERA (2020), and were $£ 160 /$ cow for wintercalving herds and $£ 150 /$ cow for spring-calving herds. However, sundry costs were assumed to be $20 \%$ lower with the crossbred cows due to their known improved health and fertility. Annual gross margins were determined by deducting variable costs from total outputs.

Given that the research was undertaken on a large research farm, it was not possible to obtain representative overhead costs for the systems examined. Estimates of overhead costs were therefore obtained from the benchmarking data for NI dairy farms during 2019-2020 (CAFRE Dairy Herd Benchmarking, College Agriculture Food and Rural Enterprise, unpublished data). Benchmarked herds categorized as "year-round calving-fully housed" ( $\mathrm{n}=50$ ), "year-round calving-fulltime summer grazing" ( $\mathrm{n}=143)$, and "spring calving" ( $\mathrm{n}=31$ ) broadly corresponded to WC-FH, WC-Con, and the SC systems, respectively, and their fixed costs ( $£ 646, £ 485$, and $£ 429$ per cow, respectively) were used in the economic analysis. A common overhead cost was used for both SC systems. These fixed costs included machinery depreciation and running costs, fuel costs, contractor charges, building depreciation, property repairs, electricity, water and rates, business costs, and miscellaneous charges. Net margin for each of the 4 systems were obtained by deducting these overhead costs from the calculated gross margins.

\section{Statistical Analysis}

Data from 17 cows were excluded from the analysis due to mastitis or udder problems $(\mathrm{n}=8)$, stomach or digestive problems $(\mathrm{n}=3)$, and miscellaneous reasons $(\mathrm{n}=6)$, with these cows treated as missing values within the analysis. Data were analyzed using GenStat Version 16.2 (VSN International Ltd.). Food intake, milk production data, parameters describing BW and BCS data at fixed time points, and continuous fertility data were analyzed using REML analysis using a repeated-measures mixed model. The model included the following terms as fixed effects: lactation number 
$(1,2,3,4+)$, year $(1,2$, or 3$)$, milk production system (WC-FH, WC-Con, SC-H, and SC-J $\times \mathrm{H}$ ), whereas cow + cow within lactation were included as random effects. Lactation length was not included within the model as differences in lactation length between systems were due in part to differences in performance within the systems. Weekly BW data and fortnightly BCS data (until wk 44 postcalving) were analyzed using REML analysis using a repeated measures mixed model, with the model containing the following terms as fixed effects: lactation number $(1,2,3,4+)$, year $(1,2$, or 3$)$, week of lactation, and system (WC-FH, WC-Con, SC-H, and SC-J $\times \mathrm{H}$ ), and system $\times$ week of lactation, whereas cow and cow within week of lactation were included as random effects. Monthly locomotion score data were analyzed using the same model, except that week of lactation was replaced by month postcalving within the model. Blood metabolite data were analyzed using a similar model, with 2 analyses undertaken in which week of lactation was defined as 2 and 6 wk postcalving (early lactation), or 10, 20,30, and $40 \mathrm{wk}$ postcalving (later lactation). Binomial fertility and health data were analyzed using a generalized linear mixed analysis (binomial distribution and logit link function) with lactation number $(1,2,3,4+)$, milk production system (WC-FH, WC-Con, SC-H, and SC$\mathrm{J} \times \mathrm{H})$, year $(1,2$, or 3$)$, and treatment $\times$ year included as fixed effects, and with cow as the random effect. The bootstrap method was used to generate standard errors of the mean, whereas significance of each fixed effect was assessed by comparing a Wald statistic against the appropriate chi-squared distribution.

\section{RESULTS}

Grass silages offered within all systems (Table 4) were well preserved, and had similar chemical compositions and nutritive values ( $\mathrm{CP}$ and $\mathrm{ME}$ contents). Maize silage offered with the WC-FH and WC-Con systems had a mean DM content of $315 \mathrm{~g} / \mathrm{kg}$ and a mean starch content of $268 \mathrm{~g} / \mathrm{kg}$ of DM. Similarly, the grazed grass offered within systems WC-Con, SC-H, and SC-J $\times \mathrm{H}$ had a mean CP and ME content of $227 \mathrm{~g} / \mathrm{kg}$ of DM and $11.7 \mathrm{MJ} / \mathrm{kg}$ of $\mathrm{DM}$, respectively. The mean ME content of the herbage offered in each of yr 1,2, and 3 was 11.6, 11.6, and $12.0 \mathrm{MJ} / \mathrm{kg} \mathrm{DM}$ (WC-Con), 11.6, 11.6, and $12.0 \mathrm{MJ} / \mathrm{kg} \mathrm{DM}(\mathrm{SC}-\mathrm{H})$, and 11.6, 11.6, and $12.1 \mathrm{MJ} /$ $\mathrm{kg} \mathrm{DM}(\mathrm{SC}-\mathrm{J} \times \mathrm{H})$.

The mean DIM with systems WC-FH, WC-Con, SC-H, and SC-J $\times$ H were $326,317,303$, and $302(P<$ $0.001)$, respectively, whereas the mean length of the dry period for cows on each of these systems was 70,71 , 80 , and $77 \mathrm{~d}(P=0.110)$, respectively (Table 5$)$. Over the lactation period, total silage intakes were higher with WC-FH than with any other system $(P<0.001)$, whereas intakes of maize silage were higher $(P<0.001)$ with WC-FH than with WC-Con. Full lactation concentrate DMI decreased from WC-FH through to the SC systems $(P<0.001)$, whereas total herbage intakes over the lactation were calculated as 2,041, 2,788, and $2,692 \mathrm{~kg}$ of $\mathrm{DM} /$ cow with systems WC-Con, SC-H, and $\mathrm{SC}-\mathrm{J} \times \mathrm{H}$, respectively. Total DMI over the full lactation decreased from WC-FH through to the SC systems $(P$ $<0.001)$. Intakes of silage, concentrates, grass, or total DM did not differ between SC-H and SC-J $\times$ H. Dry cows on the WC-Con system were calculated to have an annual grass intake of $164 \mathrm{~kg} / \mathrm{cow}$. Total forage intake (grazed grass plus grass silage) during the dry period was higher with the SC systems than with either the WC systems $(P=0.010)$.

Full lactation milk yields were higher with WC-FH than WC-Con, whereas yields with WC-Con were higher than with either of SC-H or SC-J $\times \mathrm{H}(P<0.001$; Table 6). Milk fat and protein concentrations differed between systems, being higher with $\mathrm{SC}-\mathrm{J} \times \mathrm{H}$ than with any of the other systems $(P<0.001)$, whereas milk protein content was lowest with SC-H. Yields of milk fat, protein, and fat plus protein were highest with WC-FH, and lowest with the SC systems $(P<0.001)$, with ECM yield following a similar trend. Somatic cell counts were 222, 209, 114, and $183(000 / \mathrm{mL})$ with WC-FH, WCCon, SC-H, and SC-J $\times$ H, respectively. Somatic cell score was lowest with $\mathrm{SC}-\mathrm{H}(P=0.031)$.

Cows on $\mathrm{SC}-\mathrm{J} \times \mathrm{H}$ were lighter than those on any of the other systems at calving, at drying off and at nadir BW $(P<0.001)$, while not differing from the cows on $\mathrm{SC}-\mathrm{H}$ in $\mathrm{BW}$ loss to nadir or BW gain from nadir to drying off $(P>0.05$; Table 7$)$. Holstein cows on SC-H had a lower mean BW, lower BW at drying off, and lower nadir BW than those on WC-FH or WC-Con, although these differences were not apparent at calving. Cows on WC-FH reached nadir BW fastest, and gained more BW from nadir to drying off than cows on any other system $(P<0.001)$. While there was no difference between systems in BCS of cows at calving, cows on WC-FH had a significantly higher mean BCS and BCS at dry-off than cows on any other system. There was a significant effect of system $(P<0.001)$ and of time $(P<0.001)$, and a significant system $\times$ time interaction $(P<0.001)$ on weekly BW (Figure 1$)$ and fortnightly BCS (Figure 2) over the first $44 \mathrm{wk}$ of lactation.

Days to first observed heat tended $(P=0.099)$ to be lowest with $\mathrm{SC}-\mathrm{J} \times \mathrm{H}$ (Table 8 ). Conception to first service and to first and second services were unaffected by system $(P>0.05)$. The interval from calving to conception was lower $(P<0.05)$ with $\mathrm{SC}-\mathrm{J} \times \mathrm{H}$ than with WC-FH. System had a significant effect on the 
Table 4. Mean chemical composition (SD in parentheses) of grass silage, maize silage ( $\mathrm{g} / \mathrm{kg}$ volatile-corrected DM, unless stated otherwise), and grazed grass $\left(\mathrm{g} / \mathrm{kg}\right.$ of DM, unless stated otherwise) offered during the $3 \mathrm{yr}$ of the experiment with each of the 4 systems $^{1}$

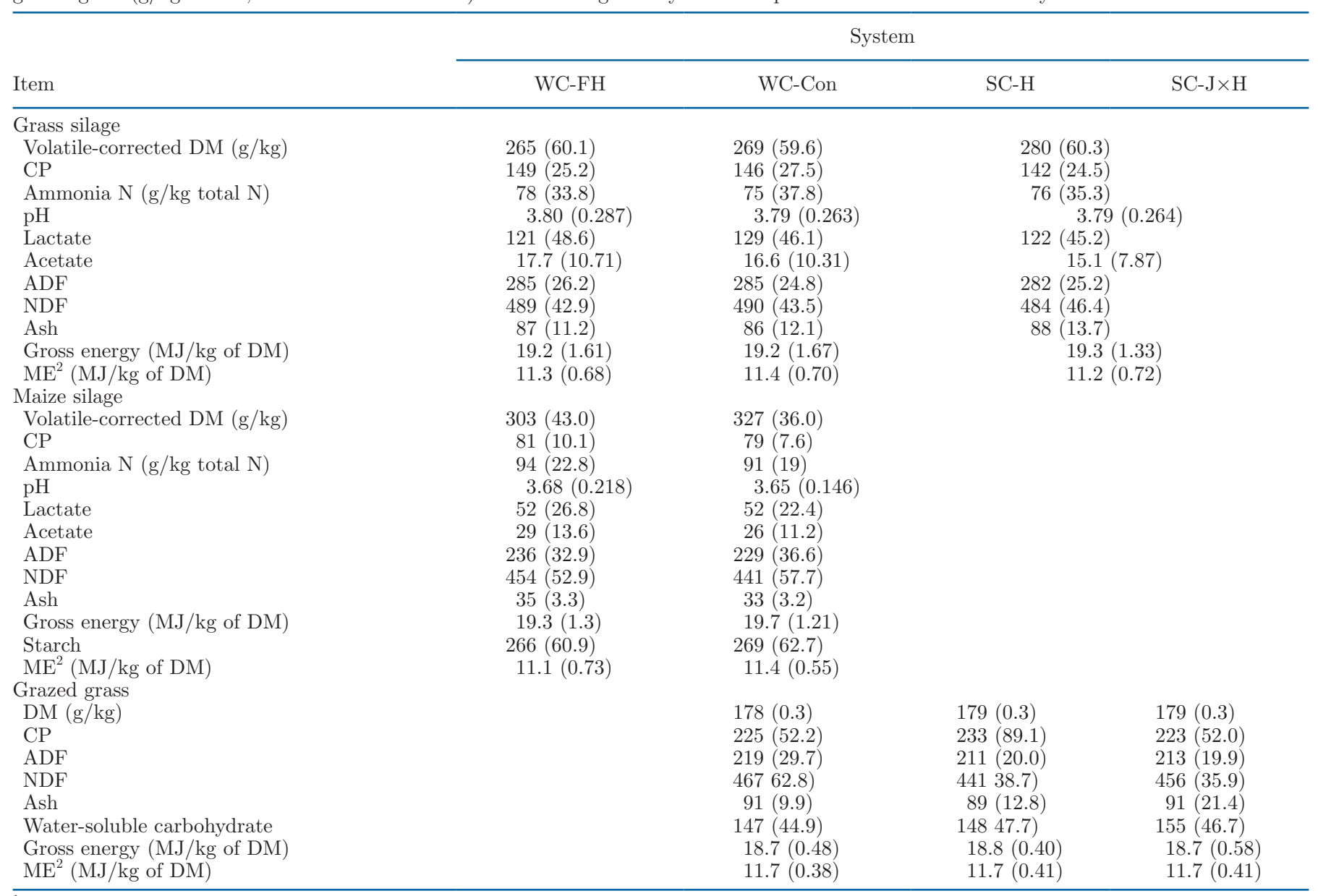

${ }^{1} \mathrm{WC}-\mathrm{FH}=$ winter calving-fully housed; WC-Con $=$ winter calving-conventional; SC-H $=$ spring calving with Holstein cows; SC-J $\times \mathrm{H}=$ spring calving with Jersey $\times$ Holstein crossbred cows. SED $=$ standard error of the differences of means.

${ }^{2}$ Predicted using near-infrared spectroscopy.

Table 5. Effect of system on days on study and total DMI $(\mathrm{kg} / \mathrm{cow})$ during the lactation and dry periods ${ }^{1}$

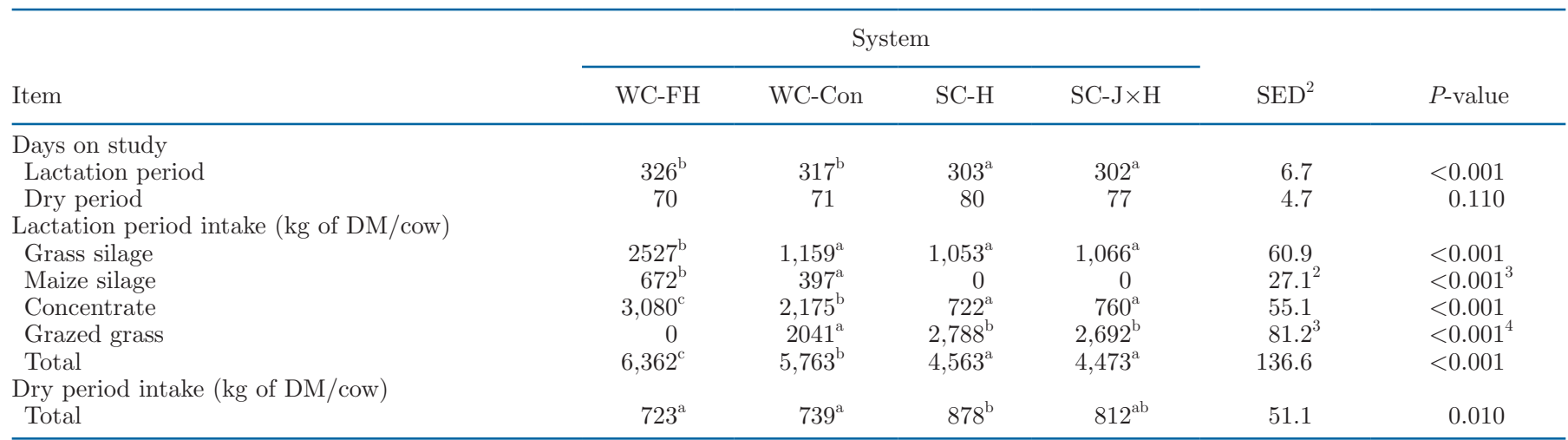

${ }^{\mathrm{a}-\mathrm{c}}$ Within a row, means with the same superscripts are not significantly different $(P>0.05)$.

${ }^{1} \mathrm{WC}-\mathrm{FH}=$ winter calving-fully housed; $\mathrm{WC}$-Con $=$ winter calving-conventional; $\mathrm{SC}-\mathrm{H}=$ spring calving with Holstein cows; SC-J $\times \mathrm{H}=$ spring calving with Jersey $\times$ Holstein crossbred cows.

${ }^{2} \mathrm{SED}=$ standard error of the differences of means.

${ }^{3}$ Comparison between WC-FH and WC only.

${ }^{4}$ Comparison between WC, SC-H, and SC-J $\times$ H only. 
Table 6. Full lactation milk production performance associated with each of the 4 systems $^{1}$

\begin{tabular}{|c|c|c|c|c|c|c|}
\hline Item & \multicolumn{4}{|c|}{ System } & $\mathrm{SED}^{2}$ & $P$-value \\
\hline Milk yield (kg/lactation) & $9,333^{\mathrm{c}}$ & $8,443^{\mathrm{b}}$ & $6,464^{\mathrm{a}}$ & $6,049^{\mathrm{a}}$ & 240.6 & $<0.001$ \\
\hline Fat & $44.9^{\mathrm{b}}$ & $43.3^{\mathrm{ab}}$ & $42.8^{\mathrm{a}}$ & $49.0^{\mathrm{c}}$ & 1.02 & $<0.001$ \\
\hline Protein & $34.6^{\mathrm{b}}$ & $34.9^{\mathrm{b}}$ & $33.6^{\mathrm{a}}$ & $36.3^{\mathrm{c}}$ & 0.48 & $<0.001$ \\
\hline Lactose & $46.0^{\mathrm{b}}$ & $45.5^{\mathrm{a}}$ & $45.1^{\mathrm{a}}$ & $45.3^{\mathrm{a}}$ & 0.25 & $<0.001$ \\
\hline \multicolumn{7}{|c|}{ Milk solids yield ( $\mathrm{kg}$ /lactation) } \\
\hline Fat plus protein & $741^{\mathrm{c}}$ & $660^{\mathrm{b}}$ & $495^{\mathrm{a}}$ & $514^{\mathrm{a}}$ & 18.3 & $<0.001$ \\
\hline ECM yield ( $\mathrm{kg}$ /lactation) & $9,934^{\mathrm{c}}$ & $8,817^{\mathrm{b}}$ & $6,640^{\mathrm{a}}$ & $6,775^{\mathrm{a}}$ & 242.5 & $<0.001$ \\
\hline $\mathrm{SCS}\left(\times 1,000 / \mathrm{mL} \mathrm{\operatorname {log } _ { \mathrm { e } } )}\right.$ & $11.76^{\mathrm{b}}$ & $11.82^{\mathrm{b}}$ & $11.34^{\mathrm{a}}$ & $11.70^{\mathrm{b}}$ & 0.176 & 0.031 \\
\hline
\end{tabular}

${ }^{\mathrm{a}-\mathrm{c}} \mathrm{Within}$ a row, means with the same superscripts are not significantly different $(P>0.05)$.

${ }^{1} \mathrm{WC}-\mathrm{FH}=$ winter calving-fully housed; $\mathrm{WC}-\mathrm{Con}=$ winter calving-conventional; $\mathrm{SC}-\mathrm{H}=$ spring calving with Holstein cows; $\mathrm{SC}-\mathrm{J} \times \mathrm{H}=$ spring calving with Jersey $\times$ Holstein crossbred cows.

${ }^{2} \mathrm{SED}=$ standard error of the differences of means.

proportion of cows with one or more cases of mastitis, with cows on $\mathrm{SC}-\mathrm{J} \times \mathrm{H}$ having fewer cases of mastitis than cows on either WC system $(P<0.05)$, whereas cows on SC-H had fewer cases of mastitis than those on WC-FH $(P<0.05)$. Whereas the proportion of cows with at least one case of lameness was unaffected by system, incidence tended to be lowest with $\mathrm{SC}-\mathrm{J} \times \mathrm{H}$ $(P=0.120)$. Mean locomotion scores decreased $(P<$
0.001) from WC-FH through to $\mathrm{SC}-\mathrm{J} \times \mathrm{H}$. In addition, locomotion score increased with time postcalving $(P$ $<0.001)$, and there was a significant system $\times$ time interaction $(P=0.008$ : Figure 3$)$.

Plasma concentrations of NEFA and glucose did not differ between systems in early lactation (mean of wk 2 and 6 postcalving, $P>0.05$ : Table 7). Urea concentrations did not differ between WC-FH and WC-Con,

Table 7. Effect of milk production system on body tissue reserves and blood metabolites ${ }^{1}$

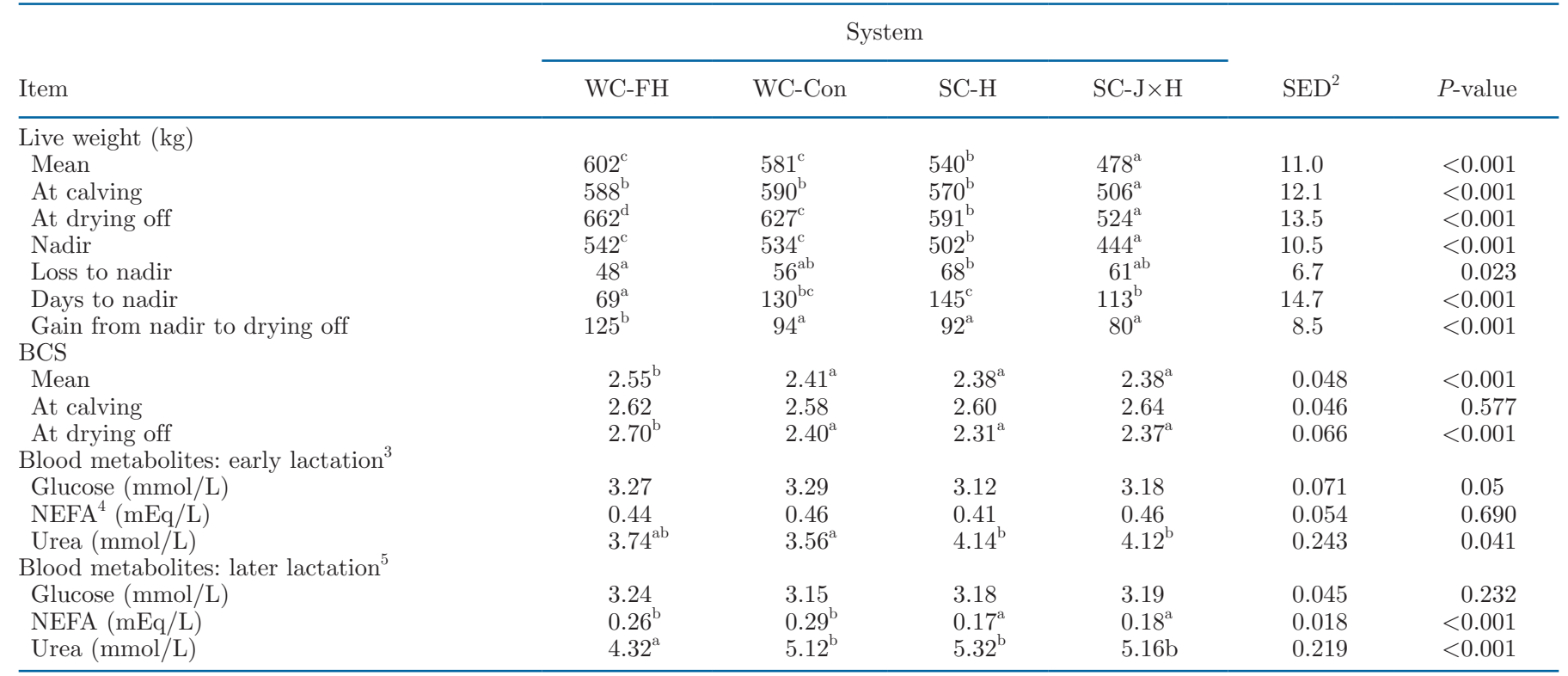

${ }^{\mathrm{a}-\mathrm{d}}$ Within a row, means with the same superscripts are not significantly different $(P>0.05)$.

${ }^{1} \mathrm{WC}-\mathrm{FH}=$ winter calving-fully housed; WC-Con $=$ winter calving-conventional; $\mathrm{SC}-\mathrm{H}=$ spring calving with Holstein cows; SC-J $\times \mathrm{H}=$ spring calving with Jersey $\times$ Holstein crossbred cows.

${ }^{2} \mathrm{SED}=$ standard error of the differences of means.

${ }^{3}$ Mean of samples taken at 2 and 6 wk postcalving.

${ }^{4} \mathrm{NEFA}=$ nonesterified fatty acids.

${ }^{5}$ Mean of samples taken at 10, 20, 30, and $40 \mathrm{wk}$ postcalving. 
whereas concentrations with SC systems were higher than with WC system $(P=0.05)$. During later lactation (wk 10, 20,30, and 40), glucose concentrations were unaffected by system, whereas NEFA concentrations were lower with WC-FH and WC-Con than with the SC systems $(P=0.05)$. Urea concentrations were significantly lower with WC-FH than with any other system $(P=0.05)$.

Total outputs $(£ /$ cow per yr) were determined as the value of milk, calves, and cull cows sold, less the annual replacement charge (Table 9 ), with values being $£ 2,486, £ 2,265, £ 1,692$, and $£ 1,747$ for WC-FH, WCCon, SC-H, and SC-J $\times$ H, respectively. Total annual variable costs/cow (feed costs plus sundry costs) were $£ 1,276, £ 990, £ 612$, and $£ 589$ for WC-FH, WC-Con, $\mathrm{SC}-\mathrm{H}$, and $\mathrm{SC}-\mathrm{J} \times \mathrm{H}$, respectively. Annual gross margins were determined by deducting variable costs from total outputs. Gross margin per kilogram of milk produced was $£ 0.141, £ 0.161, £ 0.176$, and $£ 0.199$ for WC-FH, WC-Con, SC-H, and SC-J $\times$ H, respectively (Table 9). In contrast, gross margin per hectare was highest with WC-FH, and $£ 270, £ 932$, and $£ 720$ /ha less with WCCon, SC-H, and SC-J $\times$ H, respectively. Compared with WC-FH, annual gross margin per cow were $£ 42$ higher with WC-FH, and $£ 129$, and $£ 51$ lower with SC-H and SC-J $\times \mathrm{H}$, respectively. Net margin for each of the 4 systems were obtained by deducting estimated fixed costs from the calculated gross margins. Net margin per cow/year was highest with WC-Con (£791), followed by SC-J $\times \mathrm{H}(£ 730)$ and SC-H $(£ 652)$, and was lowest with WC-FH (£564).

\section{DISCUSSION}

Although differences in performance are confounded to some extent by differences in lactation length between systems (18 d longer on average with the WC systems compared with the SC systems), differing lactation lengths were a result of the systems examined, and consequently were not removed by covariance. In addition, all production data differed between lactations, reflecting normal year-to-year variation. Consequently, this paper focuses on the mean data over the 3 -yr period as this provides a more robust long-term assessment of the performance of each system.

\section{Food Intake and Cow Performance}

The very different contributions of concentrates, conserved forages, and grazed grass to total DMI within each of the systems reflects the management systems imposed. This was perhaps most evident with concentrate DMI, which was lowest with the SC systems, intermediate with WC-Con, and highest with WC-FH, reflecting planned feeding levels. In addition, and as expected, the intake of conserved forages was significantly

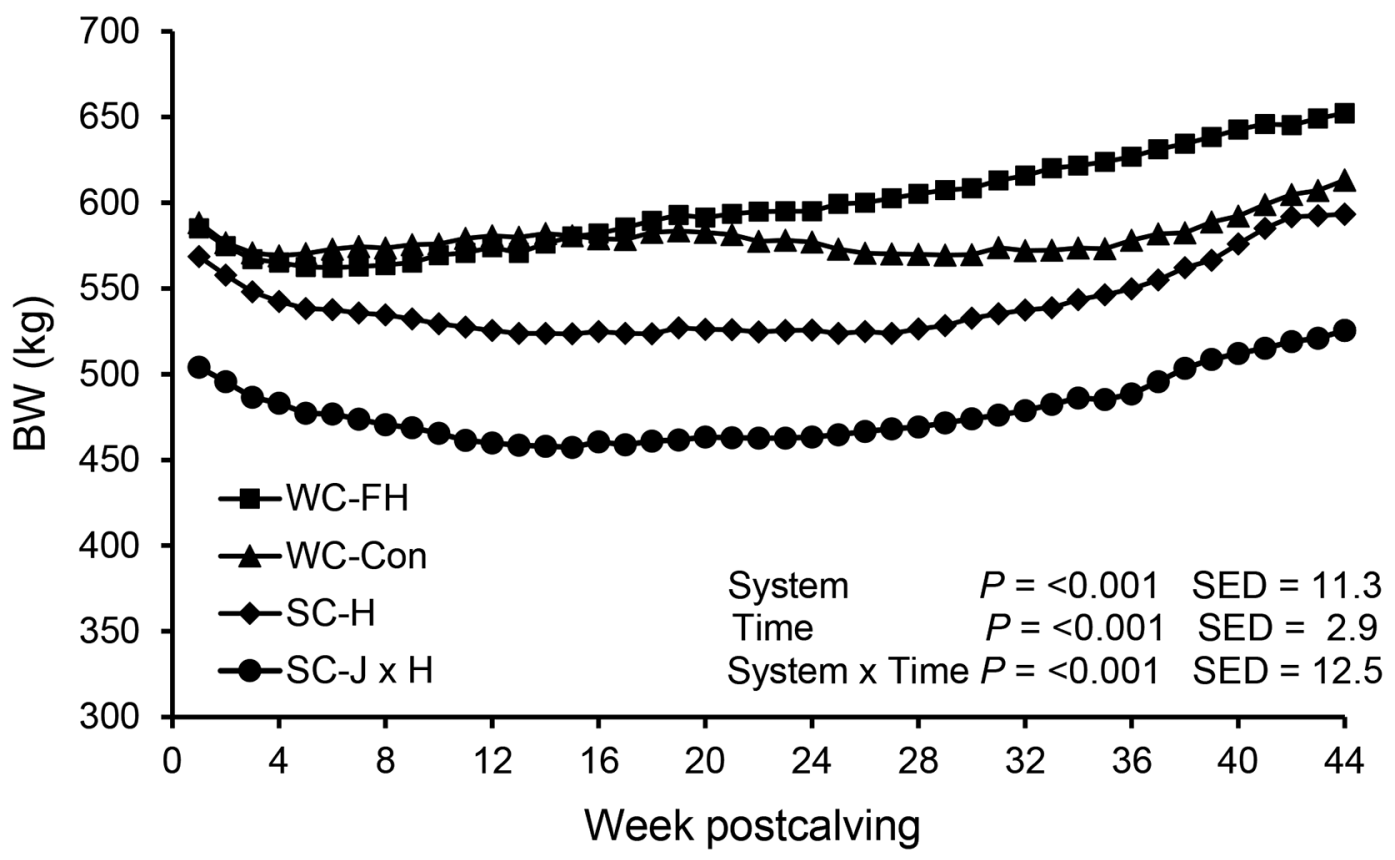

Figure 1. Effect of management system on BW change during the first $42 \mathrm{wk}$ of lactation. WC-FH = winter calving-fully housed; WC-Con $=$ winter calving-conventional; $\mathrm{SC}-\mathrm{H}=$ spring calving with Holstein cows; SC-J $\times \mathrm{H}=$ spring calving with Jersey $\times$ Holstein crossbred cows. SED $=$ standard error of the differences of means. 
Table 8. Effect of milk production system on fertility performance and cow health ${ }^{1}$

\begin{tabular}{|c|c|c|c|c|c|c|}
\hline Item & \multicolumn{4}{|c|}{ System } & $\mathrm{SED}^{2}$ & $P$-value \\
\hline \multicolumn{7}{|l|}{$\begin{array}{l}\text { Fertility performance (proportional basis unless } \\
\text { stated otherwise) }\end{array}$} \\
\hline Days to first observed heat & 54 & 52 & 48 & 40 & 6.1 & 0.099 \\
\hline Days to first service & 65 & 89 & 74 & 70 & 9.9 & 0.066 \\
\hline Conception to first service (proportion) & 0.24 & 0.27 & 0.36 & 0.38 & 0.094 & 0.419 \\
\hline \multicolumn{7}{|l|}{ Health parameter } \\
\hline Proportion of cows with one or more cases of mastitis & $0.42^{\mathrm{c}}$ & $0.41^{\mathrm{bc}}$ & $0.24^{\mathrm{ab}}$ & $0.13^{\mathrm{a}}$ & 0.083 & 0.007 \\
\hline Proportion of cows with one or more cases of lameness & 0.20 & 0.28 & 0.11 & 0.05 & 0.120 & 0.120 \\
\hline Mean locomotion score & $2.76^{\mathrm{c}}$ & $2.65^{\mathrm{b}}$ & 2. $61^{\mathrm{ab}}$ & $2.54^{\mathrm{a}}$ & 0.0511 & $<0.001$ \\
\hline
\end{tabular}

${ }^{\mathrm{a}-\mathrm{c}}$ Within a row, means with the same superscripts are not significantly different $(P>0.05)$.

${ }^{1} \mathrm{WC}-\mathrm{FH}=$ winter calving-fully housed; WC-Con $=$ winter calving-conventional; $\mathrm{SC}-\mathrm{H}=$ spring calving with Holstein cows; $\mathrm{SC}-\mathrm{J} \times \mathrm{H}=$ spring calving with Jersey $\times$ Holstein crossbred cows.

${ }^{2} \mathrm{SED}=$ standard error of the differences of means.

higher with WC-FH compared with any other system, a reflection of the absence of grazing within this system. Furthermore, the inclusion of maize silage in the diets of cows on WC-FH and WC-Con during periods when cows were housed is likely to have further increased intakes (Keady, 2005). During the grazing period, preand postgrazing sward heights, and herbage quality were similar with all systems within each year of the study, with paddock sizes and grazing management designed to achieve this. Thus the higher total herbage in- takes with the SC systems compared with WC systems largely reflects the longer grazing periods and the lower concentrate inputs during grazing with the former. In addition, there was no evidence that intakes differed between the Jersey crossbred and Holstein cows on the SC systems, although the latter were on average $62 \mathrm{~kg}$ lighter than the former. The similar intake capacity of these 2 genotypes has been demonstrated in previous studies (Prendiville et al., 2009; Vance et al., 2012b, 2013), with both Prendiville et al. (2010) and Vance

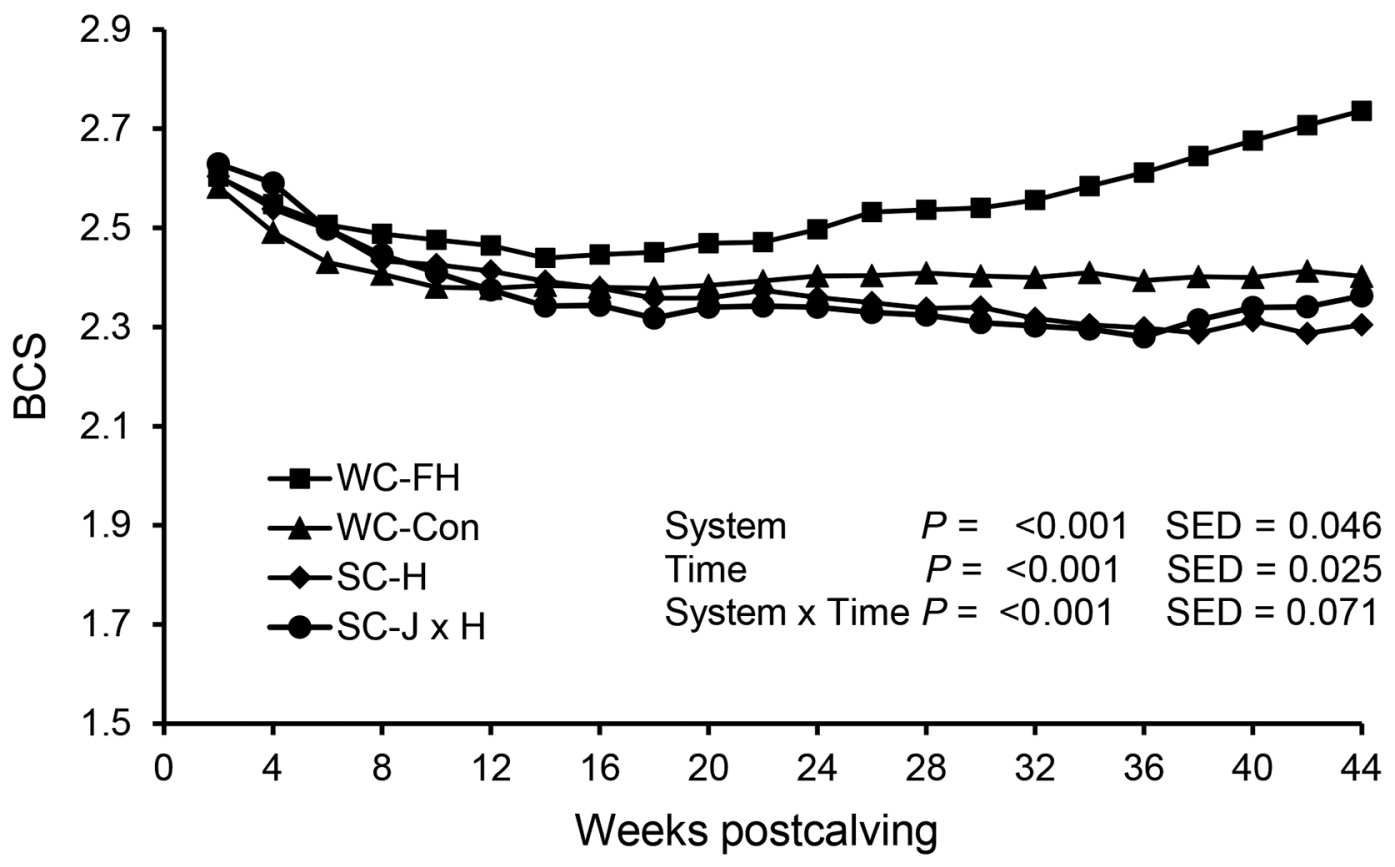

Figure 2. Effect of management system on BCS change during the first 42 wk of lactation. WC-FH = winter calving-fully housed; WC-Con = winter calving-conventional; SC-H = spring calving with Holstein cows; SC-J $\times H=$ spring calving with Jersey $\times$ Holstein crossbred cows. SED $=$ standard error of the differences of means. 
Table 9. Effect of management system on economic performance (concentrate cost, $£ 250 /$ t; milk price, $£ 0.28 / \mathrm{kg}$ ) ${ }^{1,2}$

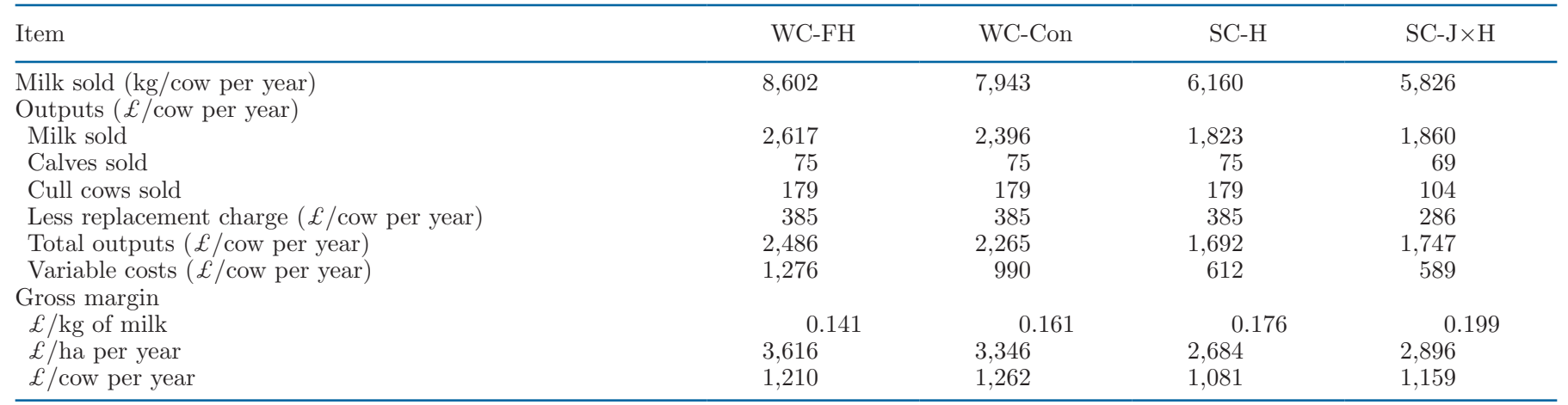

${ }^{1} \mathrm{WC}-\mathrm{FH}=$ winter calving-fully housed; WC-Con $=$ winter calving-conventional; SC-H $=$ spring calving with Holstein cows; SC-J $\times \mathrm{H}=$ spring calving with Jersey $\times$ Holstein crossbred cows.

${ }^{2} \$ 1$ USD $=£ 0.64$ GBP; Dec. 31, 2011.

et al. (2012a) observing that the feeding and grazing behavior of smaller crossbred cows differed from that of larger Holstein cows.

The increase in total DMI from the SC systems through to $\mathrm{WC}-\mathrm{FH}$ is primarily driven by concentrate intakes, and the associated increase in milk yield. While relatively few studies have attempted to present total intakes during an entire lactation, the results in the current study are similar to those recorded within similar grassland-based systems. For example, Vance et al. (2012b) recorded 305-d intakes for Holstein cows within a fully housed system (with no maize silage) of 5,813 kg of DM, whereas Ferris et al. (2003) recorded a mean DMI of winter-calving cows across a range of systems (broadly similar to WC-Con in the current study), of $5,737 \mathrm{~kg}$ in $319 \mathrm{~d}$. The higher dry period intakes of cows on the SC systems in the current study, compared with those on the WC systems reflect the longer dry period with the latter.

The ranking of the systems in terms of total milk outputs was as expected, with Holstein cows on WCFH producing $1,117 \mathrm{~kg}$ more ECM than those on WCCon, with these in turn producing $2,177 \mathrm{~kg}$ more ECM than those on SC-H. These trends reflect the trends in

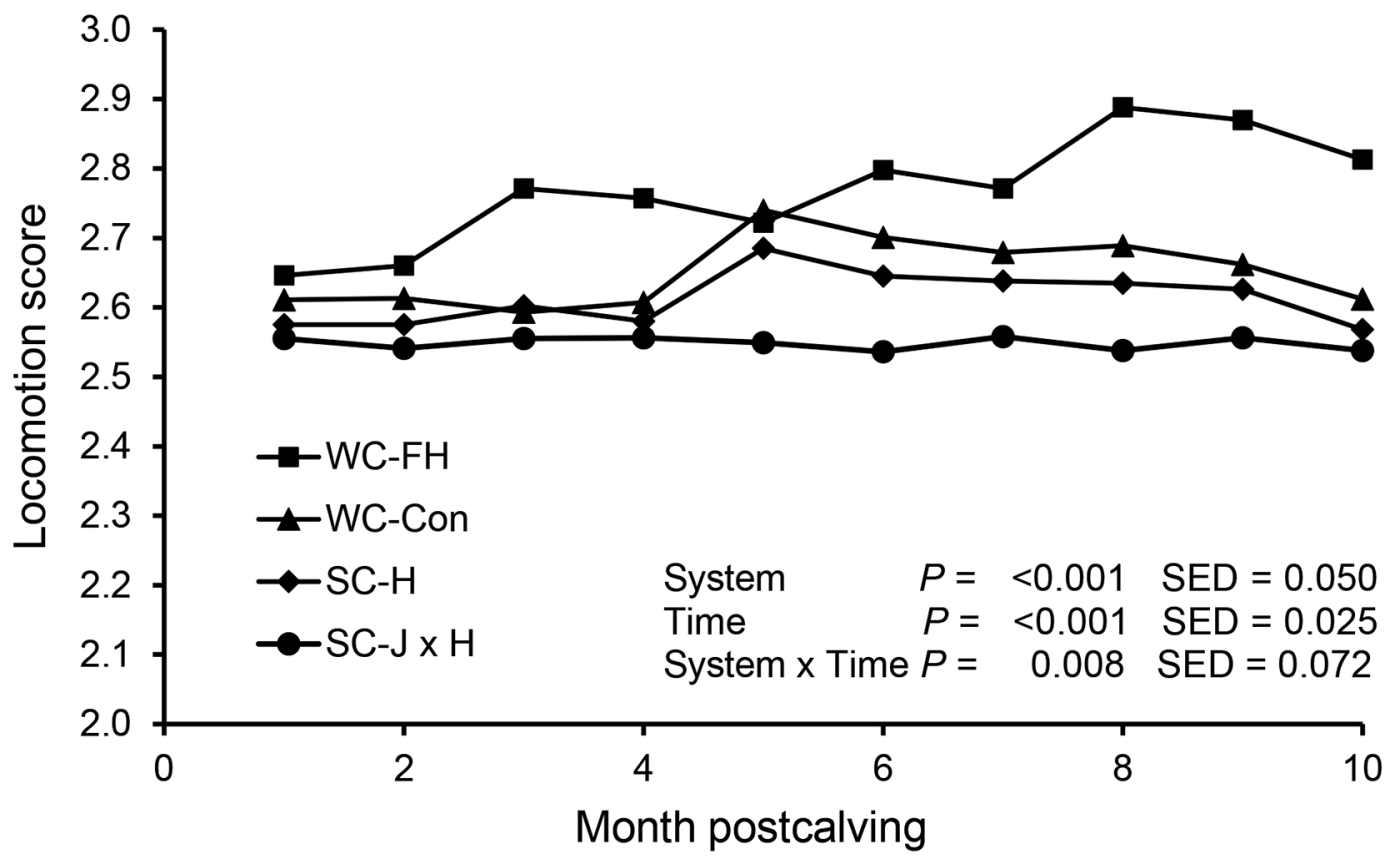

Figure 3. Effect of management system on locomotion score change during the first 10 mo of lactation. WC-FH $=$ winter calving-fully housed; WC-Con $=$ winter calving-conventional; $\mathrm{SC}-\mathrm{H}=$ spring calving with Holstein cows; SC-J $\times \mathrm{H}=$ spring calving with Jersey $\times$ Holstein crossbred cows. SED = standard error of the differences of means. 
total DMI and concentrate DMI. However, although milk yields increased with concentrate feeding, the contribution of concentrates to each kilogram of milk also increased, being $0.12,0.28$, and $0.35 \mathrm{~kg}$ of fresh concentrate/ $\mathrm{kg}$ of ECM with SC-H, WC-Con, and WC$\mathrm{FH}$, respectively. The efficiency value for WC-Con was similar to the value of 0.27 calculated by Wilkinson (2011) for the UK dairy sector. Given growing concerns about food security, the WC systems, especially WC$\mathrm{FH}$, use much more human-edible foods in the production of each liter of milk than the SC systems.

The mean ECM yield response to concentrate feeding between systems WC-Con and WC-FH was $1.23 \mathrm{~kg}$ of milk $/ \mathrm{kg}$ of concentrates DM, whereas the respective value between systems SC-H and WC-Con was 1.50. The lower ECM response with the former is reflected in the tendency for cows on WC-FH to lay down body tissue reserves as the lactation progressed. However, many other factors in addition to concentrate levels are likely to have contributed to differences in milk production between systems, including the quality and type of the forage offered (grass silage, maize silage, grazed grass) and management system (grazing vs. housed). For example, in many studies replacing grass silage with maize silage in dairy cow diets will improve milk yields (Keady, 2005). Furthermore, the quality of the conserved forages relative to grazed grass, together with grazing management, is also likely to be a key driver of differences in performance between WC-FH and the systems with a grazing component in the diet. Across the $3 \mathrm{yr}$ of the study the ME content of the grazed grass was on average approximately $0.4 \mathrm{MJ}$ higher than that of the grass silage, while the $\mathrm{CP}$ content was also substantially higher. The combined effects of these diverse factors on performance are not always easy to disentangle and quantify, with few studies having examined performance within housed and grazing systems at a common concentrate feed level. In the comparisons that do exist, conflicting outcomes have been observed, with authors finding performance to be improved (AbuGhazaleh et al., 2007), unaffected (Purcell et al., 2014), or reduced with housed systems (Mohammed et al., 2009). Similar inconsistencies have been observed in studies in which housed cows were offered higher concentrate levels than grazing cows, with authors finding performance to be improved (White et al., 2001; Vahmani et al., 2013; O'Callaghan et al., 2016), unaffected (Boken et al., 2005; Kennedy et al., 2005), or reduced with housed systems (Rego et al., 2004). These inconsistent findings across published studies are likely to reflect differences in cow genotype, forage quality, prevailing weather conditions, and management differences between systems within the different studies. In general (although not always), in studies where intake data are presented, the presence of a positive milk production response has been mirrored in a positive effect on total DMI.

We observed a general trend for milk fat content to increase with increasing levels of housing, with this reflecting the inclusion of higher fiber conserved forages in the diet for a greater proportion of the lactation. A similar effect was observed by Purcell et al. (2014), who observed a lower milk fat content with grazing cows, than with either fully or partially housed cows, despite similar levels of concentrates being offered with all treatments. Similarly, the lower milk protein levels with the SC-H than with the WC systems are likely to reflect the improved energy status of cows on the latter systems, and the higher starch content of the diets offered, a reflection of the higher concentrate levels adopted, and the inclusion of maize silage in the diets. Although previous studies have indicated that the inclusion of grazed grass in the diet normally results in improved milk protein concentrations (Ferris et al., 2008; Purcell et al., 2014), these studies were undertaken at a common concentrate feed level within grazing and housed systems, whereas the housed systems did not involve maize silage as one of the forages offered. In contrast to the findings of the current study, O'Callaghan et al. (2016) observed that cows on a grass only diet had a higher milk protein and milk fat content than housed cows offered a TMR, although the low fat content with the latter may be due in part to the high starch content of the diet offered.

The difference in performance between the Holstein and crossbred cows within the SC systems, namely a lower milk volume but improved milk composition with the crossbred cows, resulted in no overall effect on milk solids yield. This is in agreement with previous studies comparing these 2 genotypes within low and moderate concentrate input systems (Prendiville et al., 2009; Vance et al., 2013). The similar outputs of milk solids can be explained by the similar DMI with each of the 2 genotypes, which occurred despite the crossbred cows being $62 \mathrm{~kg}$ lighter, on average, than the Holstein cows.

\section{Body Tissue Changes}

Body condition score of cows on all 4 systems followed similar trends in early lactation, suggesting similar energy status at this time. This was reflected in the absence of a systems effect on serum NEFA concentrations in early lactation (wk 2 and 6 postcalving), a metabolite considered to be a good indicator of the adipose tissue lipolysis (Mäntysaari et al., 2019). Nevertheless, plasma glucose concentrations, a key driver of milk production, tended to be higher in early lactation with the WC systems, with this likely a reflection of the higher concentrate levels in the diet with these systems. 
However, when examined over the entire lactation, cows on WC-FH completed the lactation with a higher BCS than cows on any of the other systems, with these cows gaining body condition from approximately wk 12 of lactation onward. This trend was also reflected in the BW change data with this system, with these cows tending to lose less $\mathrm{BW}$ to nadir, reach nadir BW earlier (at d 69 postcalving), and gain substantially more BW from nadir to drying off. While part of the BW trend may be related to rumen fill, the BCS data provide a strong indication that these cows had an improved energy status from approximately wk 12 to 16 of lactation onward, compared with those on any other treatment. Although cows on WC-Con were managed identically to those on WC-FH in both early and late lactation, the effect of the grazing period is evident from both the BW and BCS data. For example, whereas the BW change pattern of cows on WC-FH followed a similar trend to cows on the WC system until approximately wk 20 postcalving, the BW of the latter decreased thereafter, reflecting these cows having access to grazing. This decrease is likely to reflect a rumen-emptying effect associated with grazing, as BCS data indicate little change after this time. The latter suggests that although these cows may not actually have been in negative energy balance at this time, they were gaining little body tissue.

In contrast, the BCS curves for the Holstein and crossbred cows on the SC systems follow almost identical trends, with cows appearing to lose body condition until late lactation, with a small gain observed thereafter. These trends are similar to those observed with Swedish Red crossbred cows and Holstein cows in a study involving a similar low concentrate input system (Ferris et al., 2018), with cows of both genotypes showing little evidence of BCS gain even in late lactation in that study. However, the BW data demonstrate the effect of a system with a high reliance on grazed grass, with Holstein and crossbred cows reaching nadir BW at d 145 and 113 of lactation, respectively, and gaining BW thereafter. However, perhaps surprisingly, although plasma NEFA concentrations did not differ between systems in early lactation, cows on WC systems had higher NEFA concentrations than cows on SC systems throughout the remainder of the lactation. Nevertheless, a recent analysis has demonstrated that while NEFA concentrations are a good indicator of energy balance in very early lactation, the relationship becomes poorer as lactation progresses (Cabezas-Garcia et al., 2019).

The higher serum urea concentrations with the SC systems in early lactation reflect the lower proportion of concentrate in the diet, and perhaps an undersupply of readily fermentable carbohydrate for microbial growth to utilize rumen ammonia. Throughout the rest of the lactation serum urea concentrations with WCCon and the SC calving systems were higher than with WC-FH, reflecting the inclusion of high-protein grazed grass in the diet with the former systems.

\section{Fertility Performance and Cow Health}

In agreement with findings of previous studies (Auldist et al., 2007; Vance et al., 2013), crossbred cows within the SC system tended to have improved fertility (shorter interval to first observed heat and higher conception rates), which is likely due to hybrid vigor (Lopez-Villalobos, 1998). Holstein cows on WC-FH had a longer interval from calving to conception than those on the SC-H system, although none of the other parameters differed significantly. In a recent review, Mee (2012) concluded that compared with housed cows, cows on pasture systems had increased luteal and estrous activity, and lower early embryonic mortality, although evidence of the effect of management system on conception metrics was conflicting. Furthermore, although BCS data suggest that cows on WC-FH had an improved energy status compared with cows on any other system, a recent meta-analysis of data from Holstein cows offered grass silage-based diets (Civiero et al., 2021) indicated that energy balance in early lactation was associated with an earlier return to estrus but had little effect on fertility outcomes.

There was a clear trend (although not significant for WC-Con), for Holstein cows on WC systems to have increased incidence of mastitis than cows on SC-H. Although previous studies have found an increased incidence of mastitis with housed cows, compared with grazing cows (White et al., 2001; Washburn et al., 2002), the effect of housing is confounded by other factors including milk yield (Ingvartsen et al., 2003). In addition, while higher SCC have often been observed with housed cows, factors such as cleanliness of cubicles and bedding versus cleanliness of pasture and grazing conditions can all affect cell counts of cows within different systems. The trend toward a lower incidence of mastitis with the crossbred cows compared with the Holstein cows (significantly lower than for WC-FH and WC-Con), despite no difference in SCS within these systems, is again in agreement with the findings of other studies involving crossbred cows (Vance et al., 2013; Ferris et al., 2018).

The nonsignificant trend for higher levels of lameness in cows within the WC systems, compared with the SC systems, is likely to reflect the increased duration of the housing periods and higher concentrate feed levels with these cows (Olmos et al., 2009; Chapinal et al., 2013). Whereas the exposure of the hoof to slurry within a freestall situation is likely to be a contributing 
factor to the incidence of hoof health problems, the hardness of the standing surface, increased lying times, and exercise are all likely to be additional contributing factors. Several studies have compared the hoof health of Jersey cows with a second breed, and have suggested the former have improved hoof health (Alban, 1995; Huang et al., 1995: Vance et al., 2012b), with this likely due to Jersey cows having harder hooves. However, no difference in hoof health was observed between cows on the $2 \mathrm{SC}$ calving systems in the current study.

\section{Stocking Rates and Land Use}

While actual stocking rates were measured directly within the grazing components of WC-Con and the 2 SC systems (5.1 and 4.3 cows per ha, respectively; mean across the $3 \mathrm{yr}$ of the study), forage yields were not available for the grass silages and maize silages offered within the study. To allow whole system stocking rates to be calculated, a yield of $13.0 \mathrm{t}$ of $\mathrm{DM} /$ ha was adopted for grass harvested for grass silage production (mean yield from small-scale replicated silage plots associated with this study; C. Ferris, unpublished data) and a yield of $14.2 \mathrm{t}$ of $\mathrm{DM} /$ ha was adopted for maize grown within NI (Easson, 2000). In addition, in-silo losses and feed-out losses of 13.4\% (Mayne and Gordon, 1986) and 4.0\%, respectively, were adopted. All calculations were undertaken on an annual basis, rather than on a lactation basis, with the adjustment undertaken as described earlier. Whole system stocking rates were calculated as $2.99,2.62,2.48$, and $2.50 \mathrm{cows} / \mathrm{ha}$ for $\mathrm{WC}-\mathrm{FH}$, WC-Con, $\mathrm{SC}-\mathrm{H}$, and $\mathrm{SC}-\mathrm{J} \times \mathrm{H}$, respectively. Given the large difference in annual concentrate intakes across systems, a much greater difference in stocking rate between the $\mathrm{WC}$ and $\mathrm{SC}$ systems might have been expected. That this was not observed reflects the fact that the increased concentrate feed levels were also associated with increased forage intakes, the latter being driven by the greater milk yields with the WC systems. Nevertheless, the greater stocking rate with WC-FH does demonstrates that purchased concentrates can in part replace land in situations where the latter may be limiting.

While overall stocking rates/ha were relatively similar, the systems adopted have implications for where the required land is located relative to the location of the milking facilities. For example, the SC systems had the greatest reliance on grazing, and consequently farms adopting these systems must have an adequate grazing platform within walking distance of the milking parlor to facilitate twice daily milking. While this scenario was common on the majority of farms within the United Kingdom several decades ago, increasing herd sizes combined with the fragmented nature of land blocks on many farms mean that it is frequently not possible for larger herds to walk twice daily to a sufficiently large grazing area. With system WC-Con, higher concentrate feed levels during grazing reduced the land area required during the grazing season by approximately $15 \%$. However, on many farms in the United Kingdom, cows are increasingly being housed by night over the summer months and offered either conserved forage or cut-and-carry fresh grass, thus reducing the requirement for grazing land by approximately 50\% (March et al., 2014). In addition, the adoption of full-time housed systems, as with WC-FH, can eliminate the need for grazing land altogether (March et al., 2014). With the latter approaches, forage harvested on a more distant part of the farm (either conserved, or as fresh grass) can be transported to the dairy herd, rather than the herd having to walk to the forage.

This examination of stocking rate focuses only on land used on the farm where milk is produced, and takes no account of the land that is used to grow the raw materials used in the production of concentrate feeds. For concentrate feeds offered to dairy cows within the United Kingdom, these raw materials are predominantly sourced from Europe, and from both North and South America. The land area required to grow these crops is of course important when considering the global sustainability of a milk production system, especially when these include human-edible feed ingredients such as cereal grains and pulses (Wilkinson, 2011). However, for the grassland-based dairy farmer the effect of land that is used in other parts of the world to grow concentrate ingredients is generally not part of the decision making process in relation to the optimum system to be adopted on their farm. For example, within NI one of the first limiting resources for the expansion of milk production on the majority of dairy farms is "owned land." While land may be rented, or occasionally purchased, on the majority of farms milk output on the existing land base has been increased through the increased use of concentrate feed. Nevertheless, given growing consumer concerns about the carbon-footprint of food production systems, and both ethical and environmental sustainability issues associated with growing crops, especially human edible crops, for feeding livestock, the broader impacts arising from the production of concentrate ingredients are becoming increasingly important.

Whereas overall stocking rates per hectare were relatively similar across systems, total milk output per hectare was very different, with annual outputs of $25,706,20,822,15,289$, and $14,564 \mathrm{~kg}$ of milk/ha with WC-FH, WC-Con, SC-H, and SC-J $\times \mathrm{H}$, respectively. These figure demonstrate how intensification, even within grassland-based systems, can dramatically in- 
crease milk output per unit of land areas. There are several reasons for intensification, including the desire to expand milk output where land is a limiting resource, and an attempt to spread fixed costs over a greater milk volume.

\section{Economic Performance}

While the value of milk sold per cow/year largely reflects total milk output with each system, the greater value of milk with $\mathrm{SC}-\mathrm{J} \times \mathrm{H}$ compared with $\mathrm{SC}-\mathrm{H}(£ 37$ per annum greater), despite cows on the latter system producing over $300 \mathrm{~kg}$ more milk/annum, reflects the composition bonuses adopted. Income from sales of calves and cull cows were lower with $\mathrm{SC}-\mathrm{J} \times \mathrm{H}$, reflecting the lower values adopted for Jersey crossbred calves, and the lower culling rate, although the latter was also resulted in a lower replacement cost with $\mathrm{SC}-\mathrm{J} \times \mathrm{H}$. The trends in annual variable costs per cow largely reflect the greater total feed intakes with the $\mathrm{WC}$ systems, and the greater contribution of more expensive concentrate components to the diet, especially with WC-FH.

Gross margin per kilogram of milk produced was highest with the SC systems, and decreased with increasing concentrate inputs. This demonstrates why, in a quota situation where milk output is constrained, lower cost-lower output systems normally maximize the margin associated with each kilogram of milk produced. However, with the removal of the milk quota system within the European Union, margin per kilogram of milk is now generally considered to be a less important metric. In contrast, gross margin per hectare was highest with $\mathrm{WC}-\mathrm{FH}$ and lowest with the SC calving systems, largely reflecting the higher stocking rate with the former system. Margin per hectare is an important metric, with farmer-owned land often a limiting factor on many NI farms. Nevertheless, most dairy farmers are able to rent land, albeit often some distance from the farm, whereas the use of concentrate feeds grown elsewhere (often in other parts of the world) replaces the need for land on the farm, and as such often limits the usefulness of margin/hectare as a metric.

Consequently, margin per cow is perhaps the most useful metric. Climatic conditions within NI, and indeed within most of the British Isles, necessitates that housing is required for dairy cows for most of the winter. In non-loose-housed systems, this means farmers must have a cow place or freestall available for each cow. While low cost options (e.g., roofless cubicles; O'Donovan et al., 2004) have been examined in Ireland, these are generally accepted as being inappropriate for high-yielding dairy cows. In addition, capital required to create additional cow places on most farms is substantial. Thus, on the majority of farms in NI, accommodation (available cow places) is the true limiting factor to expansion, meaning that annual margin/ cow is a key metric. Nevertheless, despite large difference between systems in the value of total outputs and in total variable costs, differences between systems in gross margin per cow were relatively modest, being highest with WC-Con, and lowest with SC-H. The relative economics (gross margin basis) of higher inputhigher output systems versuss lower input-lower output systems, is largely a balance between several conflicting issues, including the economic savings associated with the dilution of cow maintenance requirements at high milk yields, versus the higher cost diets that are necessary to achieve these higher milk outputs; the degree of partitioning of consumed nutrients to body tissue reserves versus mobilization of body tissue reserves; and the effect of nutrition and management (either positive or negative) on cow health or fertility, with associated effects on veterinary costs and calf or cull cow sales, and replacement costs. Within the current study the greater partitioning of feed nutrients to body tissue reserves with WC-FH will have had a negative effect on this economic balance, as this was not associated with any apparent fertility or health benefits.

Given that volatility in milk prices and input costs are likely to remain a permanent feature of dairy farming for the foreseeable future, optimum systems are those that are likely to be robust and resilient over a wide range of milk price-input cost scenarios. To examine this, net margin/cow was further examined across a range of milk prices, namely $£ 0.22$ (low), £0.28 (medium), and $£ 0.34$ (high) per $\mathrm{kg}$ of milk, and under a low (£250/t fresh) and high (£325/t fresh) concentrate cost scenario (Figure 4).

At both a high and medium milk price (combined with a low concentrate cost), and at a high milk pricehigh concentrate cost scenario, WC-Con had the highest net margin. This finding aligns with the modeling work of Anderson et al. (2010), which indicated that a moderate input-moderate output autumn calving system (approximately $8,000 \mathrm{~L} / \mathrm{cow}$ per year) is one of the most robust systems for NI. Although WC-FH was ranked joint second (along with $\mathrm{SC}-\mathrm{J} \times \mathrm{H}$ ) within a high milk price-low concentrate cost scenario, this system had the lowest net margin across all other scenarios examined, a reflection of the susceptibility of the system to low milk prices and high concentrate costs, together with the high fixed costs adopted. The latter reflect the more intensive nature of high input-high output systems, and the greater use of machinery and housing. The economic benefits of the spring-calving systems, especially the system involving Jersey crossbred cows, 

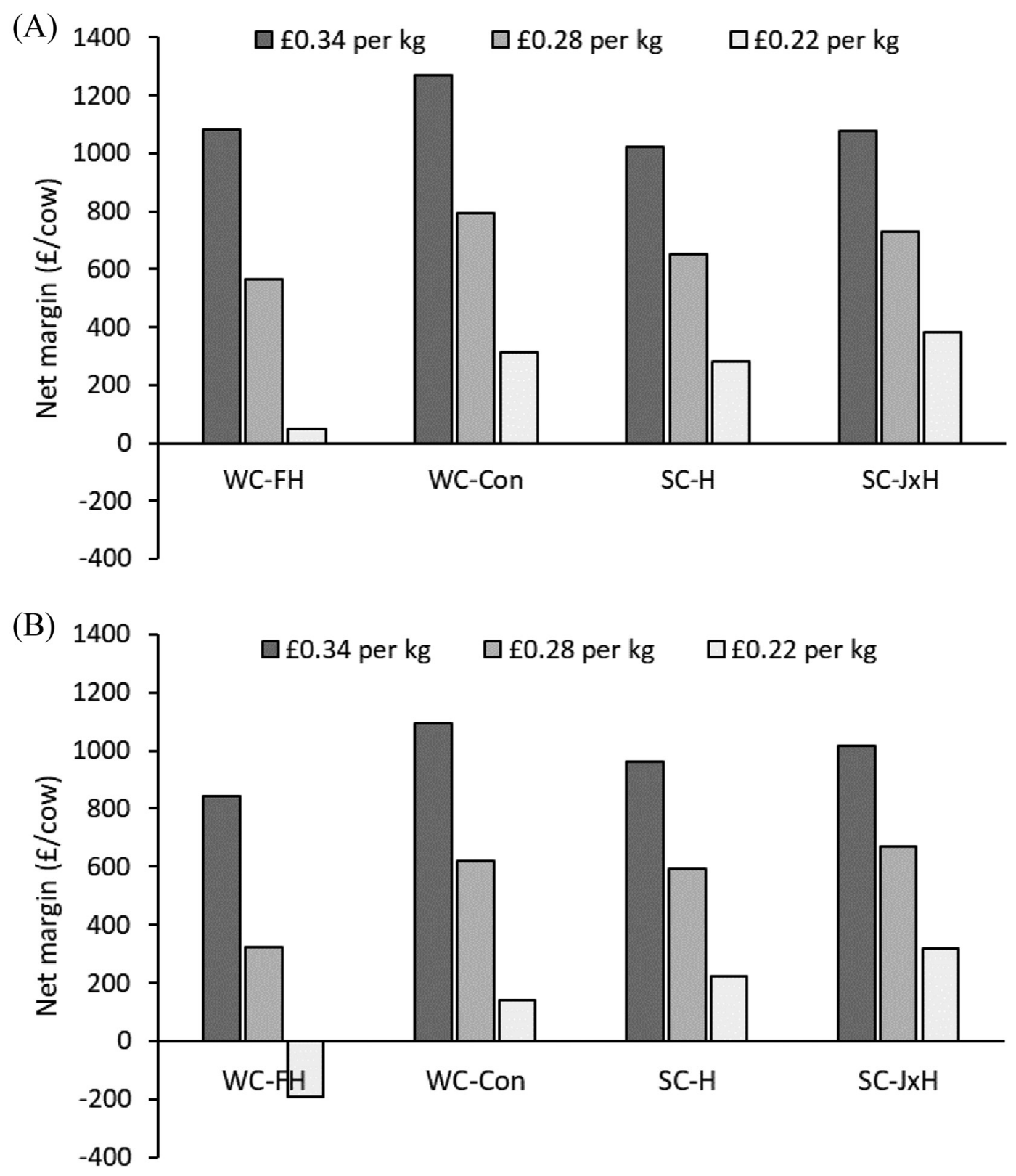

Figure 4. Effect of management system on net margin per cow/year $(£)$ across a range of milk prices $(£ 0.34, £ 0.28$, or $£ 0.22 / \mathrm{kg}$ of milk), when concentrates are costed at either (A) $£ 250$ or (B) $£ 325 /$ t fresh weight. WC-FH $=$ winter calving-fully housed; WC-Con $=$ winter calvingconventional; $\mathrm{SC}-\mathrm{H}=$ spring calving with Holstein cows; SC-J $\times \mathrm{H}=$ spring calving with Jersey $\times$ Holstein crossbred cows. $\$ 1$ USD $=£ 0.64$ GBP; Dec. 31, 2011.

became apparent at low and medium milk prices, especially under a high concentrate cost scenario. The economic performance of SC-H might appear to conflict with the findings of several studies undertaken in the Republic of Ireland (Ramsbottom et al., 2015: Hanrahan et al., 2018), which indicate that increased pasture usage and lower use of purchased feeds are key drivers of profitability under Irish conditions. However, differences in outcomes between studies may be due to a wide range of factors, including pasture growth and management, stocking rates, and cow genetics: the Holstein cows used in this study were within the top $1 \%$ of UK herds for Profitable Lifetime Index (a composite economic index) at the time of the study. Furthermore, benchmarking data from NI dairy herds (CAFRE Dairy Herd Benchmarking, College Agriculture Food and Rural Enterprise, unpublished data) demonstrates that farms adopting a wide range of production sys- 
tems, ranging from fully housed systems, through to moderate-output spring-calving systems, are normally found within the top $10 \%$ of farms, when farms are ranked by net margin. Thus it is likely that system per se is not necessarily the key driver of economic margin, but rather technical efficiency within this system. This supports the findings of Ho et al. (2013) in a study which examined Australian and New Zealand farms, with these authors concluding that the knowledge and skills of farm managers was critical, allowing many different dairy systems to perform well both physically and financially.

Although the current analysis has not examined labor requirements and costs, labor costs associated with slurry spreading and production of conserved forages, which will increase with duration of housing, are captured within the forage production costs. Although many other labor costs are not captured, it is recognized that labor costs are often not driven by system per se, but rather by infrastructure on the farm, and that a diverse range of systems can have very different labor requirements and costs, according to the facilities available and degree of mechanization adopted. While labor requirements per cow often increase as production intensity increases, milk output per labor unit normally increases with more intensive systems.

\section{CONCLUSIONS}

Food intakes and cow performance within 4 very different grassland-based milk production systems were quantified over 3 successive lactations. Total DMI and total milk output per cow increased with increasing concentrate levels. Cows on a fully housed system completed the lactation with a higher BCS than those on systems involving grazing, although this is due in to their higher concentrate intakes. Jersey crossbred cows managed on a low concentrate input system produced similar yields of milk solids as Holstein cows on the same system, despite having a lower BW. Whole system stocking rates were relatively similar between systems, although total milk output per ha increased considerably with increasing concentrate inputs. Within a medium or high milk price-lower concentrate cost scenario, net margin was highest with a moderate concentrate input-moderate milk output system, while at lower milk price-higher concentrate cost scenario, a lower concentrate input-lower milk output spring calving system had the highest net margin. This study has demonstrated that even at relatively similar stocking rates, diverse grassland-based milk production systems are associated with very different levels of performance per cow and per hectare.

\section{ACKNOWLEDGMENTS}

This work was funded by the Department of Agriculture and Rural Development in Northern Ireland (DAERA), and by AgriSearch (farmer levy). Cows on this study and the experimental protocols were managed by the staff of the AFBI Dairy Unit, and feed samples were analyzed by staff of the AFBI feed analysis laboratory. Their work is gratefully acknowledged. Thanks also go to Jason McFerran and Martin Reel (CAFRE) for the provision of economic data across a range of different systems within CAFRE Benchmarking. The authors have not stated any conflicts of interest.

\section{REFERENCES}

AbuGhazaleh, A. A., D. O. Felton, and S. A. Ibrahim. 2007. Milk conjugated linoleic acid response to fish oil and sunflower oil supplementation to dairy cows managed under two feeding systems. J. Dairy Sci. 90:4763-4769. https://doi.org/10.3168/jds.2007-0163.

Agnew, R. E., T. Yan, J. France, E. Kebreab, and C. Thomas. 2004. Energy requirement and supply. Pages $11-20$ in Feed into Milk: A New Applied Feeding System for Dairy Cows. C. Thomas, ed. Nottingham University Press.

Alban, L. 1995. Lameness in Danish dairy cows: Frequency and possible risk factors. Prev. Vet. Med. 22:213-225. https://doi.org/10 .1016/0167-5877(94)00411-B.

Anderson, D., C. Jack, N. Connolly, C. Ferris, and A. Carson. 2010. Identifying robust milk production systems. 84th Annual Conference of the Agricultural Economics Society, Edinburgh, Scotland. Agricultural Economics Society.

Arnott, G., C. P. Ferris, and N. E. O'Connell. 2017. Review: welfare of dairy cows in continuously housed and pasture-based production systems. Animal 11:261-273. https://doi.org/10.1017/ S1751731116001336.

Auldist, M. J., M. F. S. Pyman, C. Grainger, and K. L. Macmillan. 2007. Comparative reproductive performance and early lactation productivity of Jersey $\mathrm{x}$ Holstein cows in predominantly Holstein herds in a pasture-based dairying system. J. Dairy Sci. 90:48564862. https://doi.org/10.3168/jds.2006-869.

Barkema, H. W., M. A. G. Von Keyserlingk, J. P. Kastelic, T. J. G. M. Lam, C. Luby, J. P. Roy, S. J. LeBlanc, G. P. Keefe, and D. F. Kelton. 2015. Invited review: Changes in the dairy industry affecting dairy cattle health and welfare. J. Dairy Sci. 98:7426-7445. https://doi.org/10.3168/jds.2015-9377.

Boken, S. L., C. R. Staples, L. E. Sollenberger, T. C. Jenkins, and W. W. Thatcher. 2005. Effect of grazing and fat supplementation on production and reproduction of Holstein cows. J. Dairy Sci. 88:4258-4272. https://doi.org/10.3168/jds.S0022-0302(05)73112 $-\mathrm{X}$.

Cabezas-Garcia, E. H., A. W. Gordon, and C. P. Ferris. 2019. Relationships between blood metabolites and energy balance in early lactation dairy cows offered grass silage based diets: A meta-analysis. Page 74 in Advances in Biosciences - Animal Science Fit for the Future: Proceedings of the British Society of Animal Science.

Chapinal, N., A. K. Barrientos, M. A. G. von Keyserlingk, E. Galo, and D. M. Weary. 2013. Herd-level risk factors for lameness in freestall farms in the northeastern United States and California. J. Dairy Sci. 96:318-328. https://doi.org/10.3168/jds.2012-5940.

Civiero, M., E. H. Cabezas-Garcia, H. M. N. Ribeiro-Filho, A. W. Gordon, and C. P. Ferris. 2021. Relationships between energy balance during early lactation, and cow performance, blood metabolites, and fertility: A meta-analysis of individual cow data. J. Dairy Sci. 104:7233-7251. https://doi.org/10.3168/jds.2020-19607.

Craig, A., M. Mulholland, D. McConnell, and C. P. Ferris. 2021. An examination of forage production costs on Northern Irish dairy 
farms. Page 112 in The Challenge of Change, The New Normal? Proc. Br. Soc. Anim. Sci. British Society of Animal Science.

DAERA. 2020. Farm Business Data, Policy, Economics and Statistics Division, Department of Agriculture and Rural Affairs (DAERA) for Northern Ireland. Accessed Aug. 20, 2021. https://www.daera -ni.gov.uk/articles/ni-farm-performance-indicators.

Dillon, P., T. Hennessy, L. Shalloo, F. Thorne, and B. Horan. 2008. Future outlook for the Irish dairy industry: A study of international competitiveness, influence of international trade reforms and requirements for change. Int. J. Dairy Technol. 61:16-29. https:// doi.org/10.1111/j.1471-0307.2008.00374.x.

Easson, D. L. 2000. The effects of plastic mulch on the growth and development of forage maize in Northern Ireland. Pages 41-49 in The 73rd Annual Report, Agricultural Research Institute of Northern Ireland, Belfast. Agricultural Research Institute of Northern Ireland.

Edmonson, A. J., I. J. Lean, L. D. Weaver, T. Farver, and G. Webster. 1989. A body condition scoring chart for Holstein dairy cows. J. Dairy Sci. 72:68-78. https://doi.org/10.3168/jds.S0022 -0302(89)79081-0.

Ferris, C. P. 2012. An examination of the potential of crossbreeding to improve the profitability of dairying in Northern Ireland. Final Technical Report for AgriSearch, November 2012. Accessed Aug. 22 2021. https://www.agrisearch.org/publications/technical -reports/publications/technical-reports/an-examination-of-the -potential-of-crossbreeding-to-improve-the-profitability-of-dairying -in-northern-ireland-d-11-00-technical-report.

Ferris, C. P., R. C. Binnie, J. P. Frost, and D. C. Patterson. 2008. Effect of offering silage during housing at night on the performance of grazing dairy cows and on labour requirements. Grass Forage Sci. 63:138-151. https://doi.org/10.1111/j.1365-2494.2007.00621 x.

Ferris, C. P., F. J. Gordon, D. C. Patterson, C. S. Mayne, and M. A. McCoy. 2003. A short-term comparison of the performance of four grassland-based systems of milk production for autumn-calving dairy cows. Grass Forage Sci. 58:192-209. https://doi.org/10 .1046/j.1365-2494.2003.00371.x.

Ferris, C. P., P. J. Purcell, A. W. Gordon, T. Larsen, and M. Vestergaard. 2018. Performance of Holstein and Swedish-Red $\times$ Jersey/ Holstein crossbred dairy cows within low and medium concentrate grassland-based systems. J. Dairy Sci. 101:7258-7273. https://doi .org/10.3168/jds.2017-14107.

Gordon, F. J., C. P. Ferris, D. C. Patterson, and C. S. Mayne. 2000. A comparison of two grassland based systems for autumn calving dairy cows of high genetic merit. Grass Forage Sci. 55:83-96. https: //doi.org/10.1046/j.1365-2494.2000.00202.x.

Hanrahan, L., N. McHugh, T. Hennessy, B. Moran, R. Kearney, M. Wallace, and L. Shalloo. 2018. Factors associated with profitability in pasture-based systems of milk production. J. Dairy Sci. 101:5474-5485. https://doi.org/10.3168/jds.2017-13223.

Ho, C. K. M., M. Newman, D. E. Dalley, S. Little, and W. J. Wales. 2013. Performance, return and risk of different dairy systems in Australia and New Zealand. Anim. Prod. Sci. 53:894-906. https:/ /doi.org/10.1071/AN12287.

Huang, Y. C., R. D. Shanks, and G. C. McCoy. 1995. Evaluation of fixed factors affecting hoof health. Livest. Prod. Sci. 44:115-124. https://doi.org/10.1016/0301-6226(95)00062-5.

Ingvartsen, K. L., R. J. Dewhurst, and N. C. Friggens. 2003. On the relationship between lactational performance and health: Is it yield or metabolic imbalance that causes production disease in dairy cattle? A position paper. Livest. Prod. Sci. 83:277-308. https:// doi.org/10.1016/S0301-6226(03)00110-6.

Keady, T. W. J. 2005. Ensiled maize and whole crop wheat forages for beef and dairy cattle: Effects on animal performance. Silage production and utilization. R. S. Park and M. D. Stronge, ed. Pages 65-82 in Proceedings of the XIVth International Silage Conference. Wageningen Academic Publishers.

Kennedy, E., M. O'Donovan, J. P. Murphy, L. Delaby, and F. O'Mara. 2005. Effects of grass pasture and concentrate-based feeding systems for spring-calving dairy cows in early spring on performance during lactation. Grass Forage Sci. 60:310-318. https://doi.org/10 .1111/j.1365-2494.2005.00481.x.

Lopez-Villalobos, N. 1998. Effects of crossbreeding and selection on the productivity and profitability of the New Zealand dairy industry. PhD Thesis. Institute of Veterinary, Animal and Biomedical Sciences. Massey University.

Manson, F. J., and J. D. Leaver. 1988. The influence of concentrate amount on locomotion and clinical lameness in dairy cattle. Anim. Prod. 47:185-190.

Mäntysaari, P., E. A. Mäntysaari, T. Kokkonen, T. Mehtiö, S. Kajava, C. Grelet, P. Lidauer, and M. H. Lidauer. 2019. Body and milk traits as indicators of dairy cow energy status in early lactation. J. Dairy Sci. 102:7904-7916. https://doi.org/10.3168/jds.2018-15792.

March, M. D., M. J. Haskell, M. G. G. Chagunda, F. M. Langford, and D. J. Roberts. 2014. Current trends in British dairy management regimens. J. Dairy Sci. 97:7985-7994. https://doi.org/10.3168/jds .2014-8265.

Mayne, C. S., and F. J. Gordon. 1986. The effect of harvesting system on nutrient losses during silage making. 1. Field losses. Grass Forage Sci. 41:17-25. https://doi.org/10.1111/j.1365-2494.1986 .tb01787.x.

Mee, J. F. 2012. Reproductive issues arising from different management systems in the dairy industry. Reprod. Domest. Anim. 47:4250. https://doi.org/10.1111/j.1439-0531.2012.02107.x.

Mohammed, R., C. S. Stanton, J. J. Kennelly, J. K. G. Kramer, J. F. Mee, D. R. Glimm, M. O'Donovan, and J. J. Murphy. 2009. Grazing cows are more efficient than zero-grazed and grass silage-fed cows in milk rumenic acid production. J. Dairy Sci. 92:3874-3893. https://doi.org/10.3168/jds.2008-1613.

O'Brien, D., L. Shalloo, J. Patton, F. Buckley, C. Grainger, and M. Wallace. 2012. A life cycle assessment of seasonal grass-based and confinement dairy farms. Agric. Syst. 107:33-46. https://doi.org/ 10.1016/j.agsy.2011.11.004.

O'Callaghan, T. F., D. Hennessy, S. McAuliffe, K. N. Kilcawley, M. O'Donovan, P. Dillon, R. P. Ross, and C. Stanton. 2016. Effect of pasture versus indoor feeding systems on raw milk composition and quality over an entire lactation. J. Dairy Sci. 99:9424-9440. https://doi.org/10.3168/jds.2016-10985.

O'Donovan, M., G. Ryan, and G. Stakelum. 2004. A comparison of 3 grass based systems of spring milk production incorporating low fixed costs. Pages 644-649 in Proc. 20th General Meeting of the European Grassland Federation, Luzern, Switzerland. European Grassland Federation.

Olmos, G., L. Boyle, A. Hanlon, J. Patton, J. J. Murphy, and J. R. Mee. 2009. Hoof disorders, locomotion ability and lying times of cubicle-housed compared to pasture-based dairy cows. Livest. Sci. 125:199-207. https://doi.org/10.1016/j.livsci.2009.04.009.

Park, R. S., R. E. Agnew, F. J. Gordon, and R. W. J. Steen. 1998. The use of near infrared reflectance spectroscopy (NIRS) on undried samples of grass silage to predict chemical composition and digestibility parameters. Anim. Feed Sci. Technol. 72:155-167. https:// doi.org/10.1016/S0377-8401(97)00175-2.

Prendiville, R., E. Lewis, K. M. Pierce, and F. Buckley. 2010. Comparative grazing behavior of lactating Holstein-Friesian, Jersey, and Jersey $\times$ Holstein-Friesian dairy cows and its association with intake capacity and production efficiency. J. Dairy Sci. 93:764-774. https://doi.org/10.3168/jds.2009-2659.

Prendiville, R., K. M. Pierce, and F. Buckley. 2009. An evaluation of production efficiencies among lactating Holstein-Friesian, Jersey, and Jersey $\times$ Holstein-Friesian cows at pasture. J. Dairy Sci. 92:6176-6185. https://doi.org/10.3168/jds.2009-2292.

Purcell, P. J., A. J. Dale, A. W. Gordon, and C. P. Ferris. 2014. Dairy cow performance within a total-grazing, partial-confinement or total-confinement system. Page 131 in Proceedings of Agricultural Research Forum of the Irish Grassland and Animal Production Association, Tullamore, Ireland. Teagasc.

Purcell, P. J., R. A. Law, A. W. Gordon, S. A. McGettrick, and C. P. Ferris. 2016. Effect of concentrate feeding method on the performance of dairy cows in early to mid-lactation. J. Dairy Sci. 99:2811-2824. https://doi.org/10.3168/jds.2015-9988. 
Ramsbottom, G., B. Horan, D. P. Berry, and J. R. Roche. 2015. Factors associated with the financial performance of spring-calving, pasture-based dairy farms. J. Dairy Sci. 98:3526-3540. https://doi .org/10.3168/jds.2014-8516.

Rego, O. A., P. V. Portugal, M. B. Sousa, H. J. D. Rosa, C. M. Vouzela, A. E. S. Borba, and R. J. B. Bessa. 2004. Effect of diet on the fatty acid pattern of milk from dairy cows. Anim. Res. 53:213-220. https://doi.org/10.1051/animres:2004010.

Stampa, E., C. Schipmann-Schwarze, and U. Hamm. 2020. Consumer perceptions, preferences, and behavior regarding pasture-raised livestock products: A review. Food Qual. Prefer. 82:103872. https: //doi.org/10.1016/j.foodqual.2020.103872.

Tyrrell, H. F., and J. T. Reid. 1965. Prediction of the energy value of cow's milk. J. Dairy Sci. 48:1215-1223. https://doi.org/10.3168/ jds.S0022-0302(65)88430-2.

Vahmani, P., A. H. Fredeen, and K. E. Glover. 2013. Effect of supplementation with fish oil or microalgae on fatty acid composition of milk from cows managed in confinement or pasture systems. J. Dairy Sci. 96:6660-6670. https://doi.org/10.3168/jds.2013-6914.

Vance, E. R., C. P. Ferris, C. T. Elliott, H. M. Hartley, and D. J. Kilpatrick. 2013. Comparison of the performance of Holstein-Friesian and Jersey x Holstein-Friesian crossbred dairy cows within three contrasting grassland-based systems of milk production. Livest. Sci. 151:66-79. https://doi.org/10.1016/j.livsci.2012.10.011.

Vance, E. R., C. P. Ferris, C. T. Elliott, and D. J. Kilpatrick. 2012a. A comparison of the feeding and grazing behaviour of primiparous Holstein-Friesian and Jersey x Holstein-Friesian dairy cows. Ir. J. Agric. Food Res. 51:45-61.
Vance, E. R., C. P. Ferris, C. T. Elliott, S. A. McGettrick, and D. J. Kilpatrick. 2012b. Food intake, milk production and tissue changes of Holstein-Friesian and Jersey x Holstein-Friesian dairy cows within a medium-input grazing system and a high-input confinement system. J. Dairy Sci. 95:1527-1544. https://doi.org/10.3168/ jds.2011-4410.

Washburn, S. P., S. L. White, J. T. Green Jr., and G. A. Benson. 2002. Reproduction, mastitis, and body condition of seasonally calved Holstein and Jersey cows in confinement or pasture systems. J. Dairy Sci. 85:105-111. https://doi.org/10.3168/jds.S0022 -0302(02)74058-7.

Wathes, D. C., J. S. Brickell, N. E. Bourne, A. Swali, and Z. Cheng. 2008. Factors influencing heifer survival and fertility on commercial dairy farms. Animal 2:1135-1143. https://doi.org/10.1017/ S1751731108002322.

White, S. L., J. A. Bertrand, M. R. Wade, S. P. Washburn, J. T. Green Jr., and T. C. Jenkins. 2001. Comparison of fatty acid content of milk from Jersey and Holstein Cows consuming pasture or a total mixed ration. J. Dairy Sci. 84:2295-2301. https://doi.org/10.3168/ jds.S0022-0302(01)74676-0.

Wilkinson, J. M. 2011. Re-defining efficiency of feed use by livestock. Animal 5:1014-1022. https://doi.org/10.1017/S175173111100005X.

\section{ORCIDS}

C. P. Ferris (ํ) https://orcid.org/0000-0001-8623-5983

A. W. Gordon ๑ https://orcid.org/0000-0002-9806-6424 